\title{
ARTICLE \\ Whose Cultural Objects? Introducing Heritage Title for Cross-Border Cultural Property Claims
}

\section{Evelien Campfens ${ }^{1}$ (D)}

Published online: 27 August 2020

(c) The Author(s) 2020

\begin{abstract}
Cultural objects have a special, protected, status because of their intangible 'heritage' value to people, as symbols of an identity. This has been so since the first days of international law and, today, there is an extensive legal framework to protect cultural objects and to prohibit looting. Despite this, for as long as demand exists and profits are high, cultural objects continue to be looted, smuggled and traded. At some point, their character tends to change from protected heritage in an original setting to valuable art and commodity in the hands of new possessors. In this new setting, the legal status of such objects most likely will be a matter of ownership and the private law regime in the country where they happen to end up. This article suggests that, irrespective of the acquired rights of others, original owners should still be able to rely on a 'heritage title' if there is a continuing cultural link. The term aims to capture the legal bond between cultural objects and people, distinct from ownership, and is informed by international cultural heritage and human rights law norms. The proposition is that, whilst ownership interests are accounted for in national private law, legal tools are lacking to address heritage interests and identity values that are acknowledged in international law. Neither the existing legal framework for the art trade, based on the 1970 UNESCO Convention, nor regular ownership concepts appear particularly suited to solve title issues over contested cultural objects. The notion of 'heritage title' in a human rights law approach can act as a bridge in that regard.
\end{abstract}

Keywords Cultural heritage $\cdot$ Cultural property $\cdot$ Art trade $\cdot$ Human rights · International property law $\cdot$ Indigenous peoples $\cdot$ Nazi-looting $\cdot$ Colonialism $\cdot$ Provenance

Evelien Campfens

e.campfens@law.leidenuniv.nl

1 Grotius Centre for International Legal Studies; Leiden University Centre for Arts in Society, Leiden University, Leiden, The Netherlands 
'It has been claimed that culture is central to man and that without it no rights are possible since it is the matrix from which all else must spring. Culture is the essence of being human. ${ }^{1}$

\section{Introduction}

Cultural objects have a special, protected, status because of their intangible 'heritage' value to people, as symbols of an identity. This has been so since the first days of international law and, today, there is an extensive framework to protect cultural objects and to prohibit looting. Despite this, for as long as demand exists and profits are high, cultural objects continue to be looted, smuggled and traded. At some point, their character tends to change from protected heritage in an original setting to valuable art and commodity in the hands of a new possessor. In this new setting, the legal status of such an object will be a matter of ownership and the private law regime in the country where it happens to end up. This article suggests that, irrespective of the acquired rights of new possessors, original owners should still be able to rely on a 'heritage title' if there is a continuing cultural link. The term aims to capture the legal bond between cultural objects and people, distinct from ownership, and is informed by international cultural heritage and human rights law norms.

A recent Dutch case concerning a Chinese Buddha statue containing the human remains of a mummified monk may serve as an illustration. ${ }^{2}$ In 1995 the statue, dating back to the Song Dynasty (eleventh century) and revered as 'Master Zhang Gong' by the Chinese community which it came from, was stolen from a temple. It was acquired in Hong Kong by a Dutch collector who, in 2014, loaned the statue to a Hungarian museum where it was recognised by Chinese villagers as their sacred Master Zhang Gong. ${ }^{3}$ They instigated a restitution claim before the Amsterdam District Court. ${ }^{4}$ The collector, however, argued that he had bought the statue in good faith and was the lawful owner under Dutch law, claiming that at the time it was not common practice to ask for provenance details (the ownership history). Indeed, the Netherlands only issued implementation legislation for the 1970 UNESCO Convention on the Means of Prohibiting and Preventing the Illicit Import, Export and Transfer of Ownership of Cultural Property after the theft in $2009 .^{5}$ For disputes concerning artefacts that were misappropriated before that time-i.e. nearly all of

\footnotetext{
1 UNESCO Secretariat (1970), p. 10, quoted by Vrdoljak (2014), p. 139. Vrdoljak's pioneering work on the interrelation between human rights and cultural heritage law has been a source of inspiration.

2 Discussed in, e.g., Liu (2017); Hooper and Plafker (2017).

${ }^{3} N B$ During the procedure some key facts, such as the location of the statue, were not clarified.

4 Village Communities of Yangchun and Dongpu v. Van Overveem, Design \& Consultancy BV, Design Consultancy Oscar van Overveem B.V., Amsterdam District Court, Judgment of 12 December 2018, Case No. C/13/609408, ECLI:NL:RBAMS:2018:8919.

${ }^{5}$ UNESCO Convention on the Means of Prohibiting and Preventing the Illicit Import, Export and Transfer of Ownership of Cultural Property (signed 14 November 1970), 823 UNTS 231 (1970 UNESCO Convention). See the 'Uitvoeringswet UNESCO-verdrag 1970,' Staatsblad 2009, no. 255, this law was integrated in the Dutch Heritage Act of 9 December 2015.
} 
today's cases - the rule applies that a new possessor gains valid title after a good faith acquisition or merely by the passing of time. Whilst the regulation of ownership differs widely per country, this is the situation in a civil law jurisdiction like the Netherlands. ${ }^{6}$ The Dutch court denied the claim in its December 2018 ruling. ${ }^{7}$ In other words, the application of private law rules prevented the admissibility of a claim by those for whom the statue means the most, the holders of the right to practise their own religion.

The case resembles French litigation brought on behalf of the Hopi Native Americans to stop the auction of their sacred Katsina-masks representing incarnated spirits of ancestors that are referred to as 'friends' and according to Hopi law cannot be privately owned or traded. ${ }^{8}$ The Katsina were lost longer ago, in the 1930s and $1940 \mathrm{~s}$, but litigation stranded in a similar way: the French court observed that the claim that the Katsina were (inalienable) patrimony of the Hopi has no legal basis in French property law. ${ }^{9}$ Again, such an approach solely from the perspective of national private law is clearly at odds with the principles and rationale of heritage protection on the international level and the rights of indigenous peoples to use and control their (lost) ceremonial objects. To widen the scope: the field of Nazi-looted art is also typified by a striking imbalance between international (soft law) regulations that prescribe 'fair and just solutions' for disputes over family heirlooms lost as a result of racial persecution, on the one hand, and possibilities under national private law, on the other. ${ }^{10}$

Such cases highlight a tension between cultural objects as heritage-symbolic of an identity - and cultural objects as possessions-representing economic interests and exclusive rights. They also illustrate a disconnect between norms on various levels. This disconnect, it is argued, is an incentive for the trade in looted artefactsresulting in the destruction of cultural heritage $-{ }^{11}$ and a cause for legal insecurity in the art world. This article will evaluate these tensions in a search for tools to bring the various levels more into line.

It will do so by starting out with an overview of different interests and levels of law in this field (Sect. 2), and an analysis of the international regime for the art

\footnotetext{
${ }^{6}$ For the Dutch situation, see also Autocephalous Greek Orthodox Church in Cyprus v. Lans, The Hague Court of Appeal, Judgment of 7 March 2002, Case No. 99/693, ECLI:NL:GHSGR:2002:6, a denial of a claim to icons looted in the 1970s from Cyprus due to prescription. Discussed, amongst others, in Campfens (2017) and (2020).

7 Above, n. 4. In a short verdict, the claim was held inadmissible on the ground that the status of the village committees as owner of the statue was unclear.

8 Association Survival International France v. S.A.R.L. Néret-Minet Tessier Sarrou (2013) No. RG 13/52,880 BF/No. 1 (Tribunal de Grande Instance de Paris).

9 In France individual property is the known format as defined by Art. 544 of the French Civil Code. See also Kuprecht (2014), pp. 111-112; Nicolazzi et al. (2015).

${ }^{10}$ The US being the exception. For a discrepancy between the US and Western Europe see Campfens (2018).

11 On the looting from the MENA region from 1990 to 2015 '[a] large if not the major cause of damage [...] was theft from cultural institutions and illegal digging of archaeological sites to feed the voracious demand of the international market in cultural objects' rather than damage cause during military activities or fanatic of ideologues'. Brodie (2017), p. 89, cited by Gerstenblith (2020), p. 19.
} 
trade based on the 1970 UNESCO Convention and the notion of 'national treasures' (Sect. 3). This will be followed by a discussion of blind spots in this regime, such as losses that predate the UNESCO Convention or entitlement of communities or individuals to 'their' lost cultural objects, and the proliferation of soft law in that regard (Sect. 4). Section 5 elaborates on a human rights law approach to further develop this field through the notion of heritage title.

The proposition underlying this article is that, whilst ownership interests are accounted for in national private law, legal tools are lacking to address heritage interests and identity values that are acknowledged in international law. The notion of 'heritage title' acts as a bridge in that regard.

\section{Ownership versus Heritage}

Cultural objects have a dual nature, as is illustrated by the two ways they are referred to: either as 'cultural property' or as 'cultural heritage'. ${ }^{12}$ Similarly, disputes over lost cultural objects can be approached as a matter of stolen property or as lost heritage: this activates different norms. Whereas property and its ownership are mainly regulated by national private law, norms protecting heritage are predominantly of a public international law nature. What follows is an outline of how the international framework accounts for this.

\subsection{Ownership}

On the one hand, cultural objects can be seen as possessions. As such, they can be traded and owned, and are subject to property law regimes and international trade law regulations. The regulation of property and ownership, traditionally, is a matter of national sovereignty. ${ }^{13}$

Ownership can be defined as 'the greatest possible interest in a thing which a mature system of law recognises'. ${ }^{14}$ Apart from this common feature, major differences exist, most notably between common and civil law jurisdictions, with many variations on the theme of whether and how title over a (stolen) good can

\footnotetext{
12 Fiorentini et al. (2016), p. 11; Prott and O'Keefe (1992). The term 'cultural heritage' was first introduced in the Hague Convention for the Protection of Cultural Property in the Event of Armed Conflict (signed 14 May 1954), 249 UNTS 240, and ever since then has been used in legal texts alongside the term 'cultural property'. Much has been written on these terms. Hafstein and Skrydstrup (2017) for example argue that 'property is associated with technologies of sovereignty and heritage with technologies of reformation'. In the author's view, heritage protection will remain problematic as long as the private law aspects of cultural property are not sufficiently addressed from an international perspective.

13 For example, even within the EU Art. 345 of the Treaty on the Functioning of the European Union (TFEU) regulates that: 'The Treaties shall in no way prejudice the rules in Member States governing the system of property ownership'. TFEU Consolidated version [2012] OJ C 326, p. 194. For an analysis of how international law increasingly influences property relations, see Sprankling (2014).

14 Dromgoole (2013), p. 96.
} 
be transferred to a new possessor. ${ }^{15}$ Where misappropriated cultural property is concerned, the situation becomes even more fragmented as stolen artefacts tend to surface only years or decades later, by which time they may have crossed many borders. At that point, private international law should guide judges to a just outcome. Two problems occur at this level. First, ownership disputes regarding movable goods are regulated by the law of the country where the object is located at the time of a transaction (lex rei sitae). ${ }^{16}$ This enables (invites) the 'laundering' of looted objects through jurisdictions that allow for a transfer of the ownership title of stolen goods after a bona fide acquisition or merely by the passage of time. A second stumbling block is that foreign public law will not generally be applied in another jurisdiction. Export laws or laws that render certain cultural objects inalienable in their original setting - as a res extra commercium - , however, often form the basis of the unlawfulness of a taking. ${ }^{17}$ These complications are addressed in international instruments-most notably the 1995 UNIDROIT Convention on Stolen or Illegally Exported Cultural Objects - that promote the harmonisation of private law on the following points ${ }^{18}$ :

- The law of the source country—-the lex originis — should determine the (un)lawfulness of a transfer ${ }^{19}$;

- Extension of limitation periods for title claims ${ }^{20}$; and

\footnotetext{
15 Whereas civil law countries opt for security of transactions and a new possessor may gain title after a bona fide transfer, in common law countries a thief cannot transfer title (the 'nemo dat (quod not habet)' rule). These differences surface in cross-border disputes, e.g. in a case concerning a Pissarro painting, lost by its Jewish owners during the Second World War, that has been pending before the US courts for over fifteen years. After several transfers across various jurisdictions, the Pissarro is now in the possession of a Spanish museum which gained lawful ownership title under Spanish private law. (Cassirer $v$. Thyssen-Bornemisza Collection Foundation, No. 05-CV-03459 (C.D. Cal. 2019)). For further analysis, Campfens (2019b).

${ }^{16}$ Gordley (2013), p. 110; Chechi (2014), pp. 90-96; Siehr (2015), pp. 503-515.

${ }^{17}$ Chechi (2014), p. 92: '[I]n the absence of inter-State agreements, the domestic norms prohibiting or restricting the export of cultural materials are not enforced in foreign States'. In the UK, e.g., Attorney General of New Zealand v. Ortiz [1982] 3 All ER 432. Recent UK and US case law in the category of antiquities circumvent this by accepting State ownership as a sufficient basis for a claim: Government of the Islamic Republic of Iran v. The Barakat Galleries Ltd. [2007] EWCA Civ. 1374; United States v. Schultz, 178 F. Supp. 2 d445 (SDNY 3 January 2002).

${ }^{18}$ UNIDROIT Convention on Stolen or Illegally Exported Cultural Objects (signed 24 June 1995, entry into force 7 July 1998), 2421 UNTS 457 (1995 UNIDROIT Convention). The 1970 Convention does not regulate private law issues. More in Sect. 3.

191995 UNIDROIT Convention, Art. 3(2); cf., Arts. 2, 3 and 4 of the resolution on the International Sale of Works of Art from the Angle of the Protection of the Cultural Heritage (1991) of the Institut de Droit international, https://www.idi-iil.org/app/uploads/2017/06/1991_bal_04_en.pdf (1991 IDI Basel Resolution). See also the new EU import regulation (Regulation (EU) 2019/880 of 17 April 2019 on the introduction and the import of cultural goods [2019] OJ L 151), Recital at (8). As Chechi observed, however, there is no convergence (as yet) over the primacy of the lex originis. Chechi (2014), pp. 92 and 97.

${ }^{20} 1995$ UNIDROIT Convention, Art. 3(3), (4), (5) and (8), Art. 5(5); 1991 IDI Resolution, Art. 4(1) on this: '[...] may claim, within a reasonable time $[\ldots]$ '.
} 
- Invalidation of a title transfer to a new possessor, who may be entitled to compensation insofar as it can prove to have been duly diligent at the time of acquisition. $^{21}$

This would support a smooth and licit international art trade in the future. However, Western 'market countries' mostly did not accede to the 1995 UNIDROIT Convention (precisely because it deals with ownership) and have only recently become party to the 1970 UNESCO Convention (that is implemented in different ways), and today's restitution claims deal with past losses. As a result, the fragmented situation continues. To retroactively declare that the lawfully acquired ownership title of a new possessor is invalid is problematic-mostly for civil law countries where ownership over stolen goods may pass-, as that would implicate expropriation. ${ }^{22}$ It is unlikely that States would ever change their laws in that way, ${ }^{23}$ hence the preference for the extralegal 'ethical' model and alternative dispute resolution for claims to Nazi-looted art. $^{24}$

There are two more reasons why an ownership approach is problematic. Firstly, the zero-sum outcome of ownership disputes may at times obstruct rather than assist dispute resolution while other forms of entitlement may exist, such as rights to access, control, custody and the like. ${ }^{25}$ An open view, beyond an outcome in terms of exclusive and absolute ownership rights, may well pave the way to cooperative solutions. ${ }^{26}$ Secondly, in an ownership approach the (un)lawfulness of the loss in the past will be the central point of reference, whereas today's interests may be more relevant, such as the (continuing) spiritual importance of cultural objects. ${ }^{27}$

In other words, there are limitations to a strict ownership approach to solve cultural property disputes - as cases that concern stolen property-and this is a consequence of the special nature of cultural objects. How this is accounted for in the legal framework will be discussed next.

\footnotetext{
${ }^{21} 1995$ UNIDROIT Convention, Arts. 4 and 6; 1970 UNESCO Convention, Art. 7(b)(ii) that sees to the return of documented objects stolen from a public institution; 1991 IDI Basel Resolution, Art. 4(2), (3).

${ }^{22}$ And this could violate the human right to property and would require compensation. Universal Declaration of Human Rights (UDHR), Art. 17; First Protocol to the European Convention for the Protection of Human Rights and Fundamental Freedoms, adopted 20 March 1952, ETS 9. Art. 1: 'Every natural or legal person is entitled to the peaceful enjoyment of his possessions. No one shall be deprived of his possessions except in the public interest and subject to the conditions provided for by law and by the general principles of international law'.

${ }^{23}$ Robertson (2019), p. 312, proposes a Convention for the Repatriation of Important Cultural Heritage that should retroactively apply with time limitations set at 275 years. In the view of the author such a time period will remain arbitrary, underscoring the need for an alternative approach.

${ }^{24}$ On the ethical model for Nazi-looted art claims, Campfens (2017) and (2020).

${ }^{25}$ Given that ownership could be seen as a 'bundle of rights': the right to control, including the right to exclude others; the right to alienate; the right to exploit; and the right to destroy. Dromgoole (2013), p. 97.

${ }^{26}$ Further to be discussed in Sect. 5.3.

${ }^{27}$ Ibid.
} 


\subsection{Heritage}

From a heritage point of view, cultural objects are valued because of their intangible value to people: as symbols of an identity. Throughout history and in most cultures, objects that are meaningful to the (own) community enjoy special legal status. Illustrative in this respect is a 1925 Indian court ruling holding that a contested Hindu family idol 'could not be seen as a mere chattel which was owned'. ${ }^{28}$

This intangible heritage value has been the rationale underlying the protected status of cultural objects in international law since its foundation..$^{29}$ In the much cited words of Justice Croke in 1813, by which he released artefacts that had been seized (as war booty) during the Anglo-American War: 'The arts and sciences are admitted amongst all civilized nations, [...] as entitled to favour and protection. They are considered not as the peculium of this or that nation, but as the property of mankind at large, and as belonging to the common interests of the whole species'. ${ }^{30}$ Cultural objects, in other words, deserve protection and immunity, even in times of war, and this is a matter of universal concern as they are 'the property of mankind'.

\subsubsection{Property of Mankind?}

The interest of 'mankind' or 'humanity' is often invoked in declarations or preambles in the field of heritage protection. ${ }^{31}$ It underlines a shared, universal interest and responsibility to safeguard cultural objects. But what does this mean? It may give the impression that some international authority is in place to oversee the protection and just dissemination of cultural objects (like the global commons). ${ }^{32}$ That, however, is not the case. States are appointed as custodians in this regard and no specialised authority or international compliance mechanism is in place. ${ }^{33}$

\footnotetext{
${ }^{28}$ Mullick v. Mullick (1925) LR LII Indian Appeals 245, cited in Prott and O'Keefe (1992), p. 307. However, as shown in the examples in the introduction, when it comes to the protection of foreign heritage interests such special treatment is not a given.

${ }^{29}$ On the historical development, e.g. Campfens (2019a).

${ }^{30}$ Vice-Admiralty Court of Halifax, Nova Scotia Stewart's Vice-Admiralty Reports 482 (1813), reproduced in Merryman (1996), p. 321.

${ }^{31}$ E.g. Preamble to the 1954 Hague Convention (above n. 12): 'Being convinced that damage to cultural property belonging to any people whatsoever means damage to the cultural heritage of all mankind, since each people makes its contribution to the culture of the world'.

${ }^{32}$ I.e. the legal frameworks for resources of the ocean floor, Antartica, outer space and the Moon that aim at cooperation and sharing by all, instead of appropriation by some. The Convention on the Law of the Sea, 10 December 1982, 1833 UNTS 397 (UNCLOS), in Art. 137, establishes such an international authority to oversee the equitable sharing of mineral resources on the deep seabed of the high seas-the 'Area' in UNCLOS terms: 'All rights in the resources of the Area are vested in mankind as a whole, on whose behalf the [International Seabed] Authority shall act'. See also the Agreement Governing the Activities of States on the Moon and Other Celestial Bodies, 1979, 1363 UNTS 3, Art. 4. See Schrijver (2016).

${ }^{33}$ In fact, even cultural objects found in shipwrecks in the high seas do not fall under the competency of the International Seabed Authority but are linked to States. Arts. 133(a) and 136 of UNCLOS limit the concept of 'Heritage of Mankind' to minerals. In the UNESCO Convention on the Protection of the Underwater Cultural Heritage of 2 November 2001 (entered into force on 2 January 2009), 2562 UNTS 3 , nevertheless, a coordination system is set up to ensure the safeguarding of underwater cultural heritage. In this system, States with a verifiable link have 'preferential rights', see Art. 11: 'Any State Party
} 
This does not mean, on the other hand, that the legal status of cultural objects is solely a matter of national sovereignty. Binding international norms do influence their legal status, as illustrated by the role that the UN Security Council has recently adopted in this field. In the name of peace and security it has introduced a ban on the trade in and possession of looted cultural objects from Syria and Iraq. ${ }^{34}$ In more general terms, in its 2017 Resolution the Security Council calls upon States to adopt measures to curb the trade and trafficking in cultural property and other items of archaeological, historical, cultural, rare scientific, and religious importance originating from a context of armed conflict' as this 'can fuel and exacerbate conflict and hamper post-conflict national reconciliation, thereby undermining the security, stability, governance, social economic and cultural development of affected states'. ${ }^{35}$ These Resolutions are a further confirmation of the binding status of the prohibition on looting cultural objects in times of armed conflict. ${ }^{36}$ On the other hand, as Gerstenblith points out, the fact that such ad hoc and directly binding action by the Security Council is necessary to ensure not only that the act of looting is unlawful but that the illegality 'sticks' to the object, highlights the weaknesses of the regular regime for the art trade. ${ }^{37}$ This will be further discussed in Sect. 3.

Also beyond the category of armed conflict international norms exist that overrule national interests. In this respect, the key principle in the 1970 UNESCO Convention that the unauthorized transfer of cultural objects is illicit may be contrary to the interests of so-called market States. In all its ambiguity, it has been invoked by national courts as international public policy. ${ }^{38}$

The notion 'property (or: heritage) of mankind' may therefore, in the present context, best be understood to underline that the protection of cultural objects in terms of preservation and accessibility is a matter of international public policy.

\footnotetext{
Footnote 33 (continued)

may declare to the Director-General its interest in being consulted on how to ensure the effective protection of that underwater cultural heritage. Such declaration shall be based on a verifiable link to the underwater cultural heritage concerned, particular regard being paid to the preferential rights of States of cultural, historical or archaeological origin'. For a discussion, see Dromgoole (2013), p. 120.

34 As a matter of peace and security these resolutions contain obligations imposed on all States, aimed at the return of objects to the people they came from: UNSC Res. 2199 (S/RES/2199, 2015), para. 17: 'decides that all Member States shall take appropriate steps to prevent the trade in Iraqi and Syrian cultural property and other items of archaeological, historical, cultural, rare scientific, and religious importance illegally removed from Iraq since 6 August 1990 and from Syria since 15 March 2011, including by prohibiting cross-border trade in such items, thereby allowing for their eventual safe return to the Iraqi and Syrian people [...]'; UNSC Res. 1483 (S/RES/1483, 2003), para. 7. These are both based on Arts. 39 and 41 of Chapter VII of the UN Charter.

35 UNSC Res. S/RES/2347 (2017).

36 E.g. Francioni (2019), p. 406: as general principles of law or customary law; Hausler (2020), p. 204.

37 Gerstenblith (2020), pp. 37-43.

38 The ambiguous character of this term will be discussed in the next sections.
} 


\subsubsection{Preservation and Accessibility}

The traditional concern of international law in cultural heritage has been its preservation: to protect it from harm. ${ }^{39}$ The destruction of cultural heritage has been prohibited since the early days of international law and perpetrators have been convicted by international tribunals: Rosenberg after the Second World War for his part in wide scale Nazi looting and destruction of monuments, and more recently $\mathrm{Al}$ Mahdi for the destruction of cultural heritage in Timbuktu. ${ }^{40}$ In the context of this article it is important to realize that the allowance of a market for looted cultural objects is an incentive for the destruction of sites of cultural importance.

Apart from preservation, accessibility for the public is also acknowledged as a valid interest that may limit the rights of owners. In that sense, the European Court of Human Rights in the Beyeler case held that it is legitimate for States to take measures that limit private property rights, in order to facilitate wide public access to works of art lawfully on its territory. ${ }^{41}$ The case concerned a complaint against the Italian government by a private owner of a Van Gogh painting that he acquired in Rome and wished to export. The Italian government denied permission and intended to use its right of pre-emption to the painting under Italian heritage law: the owner argued that this was a violation of the right to property under Article 1 of the First Protocol to the European Convention on Human Rights. ${ }^{42}$ Although the Court indeed found a violation due to the lack of a fair balance in the way in which the right of pre-emption was exercised (creating a situation of uncertainty), it held that control of the art market by a State is a legitimate aim for the purposes of protecting a country's cultural and artistic heritage. ${ }^{43}$ As to the question of how this relates to foreign artefacts - the Van Gogh being a painting by a Dutch artist -, the Court referred to the concept of the 'cultural heritage of all nations' and linked it to the public's right to have access to it. In other words, restrictions on property rights may well be justified to uphold the (cultural) rights of others, in this case the wider public. ${ }^{44}$ Similarly, in a 2019 appeals procedure in Canada the export prohibition of a French painting that an English buyer had acquired from a private Canadian

\footnotetext{
${ }^{39}$ Destruction in the context of armed conflict constitutes a violation of international humanitarian law, but, beyond the context of armed conflict, it may affect human rights. See UNHRC, Res. 6/11 on Protection of Cultural Heritage as an Important Component of the Promotion and Protection of Cultural Rights, UN Doc. A/HRC/RES/6/11 (28 September 2007), Preamble. See also the UNESCO Declaration Concerning the Intentional Destruction of Cultural Heritage Paris (17 October 2003), UNESCO Doc. 32/Res 33, and the UNSC Resolutions mentioned above.

${ }^{40}$ Prosecutor v. Ahmad al Faqi al Mahdi, Judgment and Sentence, ICC-01/12-01/15-171, 27 September 2016.

${ }^{41}$ Beyeler v. Italy [GC], no. 33202/96, ECtHR, Judgment of 5 January 2000, ECHR 2000-I, (2001) 33 EHRR 52.

42 Above n. 22.

43 Above n. 41 (§ 112) and Council of Europe, Research Division (2011), p. 19.

${ }^{44}$ Maltese law provides for an export prohibition and a right of pre-emption with regard to any 'object of cultural, artistic, historical, ethnographic, scientific or industrial value, even if contemporary, that is worth preserving' that has been brought onto Maltese territory, even with regard to (foreign) artefacts that were recently imported into Malta. This would seem to overstretch the public interests at stake. In the UK and France, e.g., the threshold is a 50-year period of being within the country. See De Gaetano (2019).
} 
collector was deemed legitimate, since the aim was to enable Canadian museums to acquire the painting. ${ }^{45}$ As in many other countries, the Canadian Heritage Act enables such measures if an object is of 'outstanding significance' and of 'national importance'. If no offer by a Canadian museum is made within a certain period, the export permit will be issued. ${ }^{46}$ Whereas such measures are justified in the name of wide accessibility to 'universal heritage', a prerequisite is that the artefact is 'lawfully' within that country, in other words that there are not others with a stronger (heritage) title.

\subsubsection{Preservation and Accessibility: For Whom?}

Where should cultural objects be preserved and who is most entitled to access them is not answered by reference to preservation and accessibility alone. On the one hand, the preservation of cultural heritage in situ is increasingly acknowledged as important for the sustainable development of societies. ${ }^{47}$ The integrity of monuments and archaeological sites deserves special attention in this regard. On the other hand, this does not mean that cultural objects ought always to remain in, or be returned to, their original setting: the dissemination of culture is also widely recognised as important 'for the well-being of humanity and the progress of civilisation'. ${ }^{48}$

The so-called cultural property internationalists - a term introduced by John Henry Merryman-take it a step further. ${ }^{49}$ They advocate a liberal trade in cultural objects and argue that physical preservation and wide accessibility are the public interests at stake in heritage protection as this serves humanity as a whole, wherever the objects may be. This argumentation has long been used by Western museums to deny return claims by source communities, claiming that these interests are best guaranteed in a 'universal' museum. ${ }^{50}$ It has also been widely criticised as

\footnotetext{
45 Canada (Attorney General) v. Heffel Gallery Limited, 2019 FCA 82 (CanLII), https://canlii.ca/t/hzt66 (accessed 30 July 2020). Overruling an earlier verdict that held the measure to be unreasonable as it concerned a French painting that had never been on public display in Canada.

46 Ibid., para. 56.

47 'Safeguarding of the world's cultural and natural heritage' is listed as Sustainable Development Goal no. 4, target 7, UNGA 25 September 2015 (A/Res/70/1), Transforming Our World: the 2030 Agenda for Sustainable Development (25 September 2015), UN Doc. A/RES/70/1 (31 October 2015), paras. 4.7 and 11.4; see, e.g., also the SC Resolutions discussed above (n. 34) aiming at return 'to the Iraqi and Syrian people'.

${ }^{48}$ In the preamble to the 1995 UNDROIT Convention this tension is noticeable: 'Convinced of the fundamental importance of the protection of cultural heritage and of cultural exchanges for promoting understanding between peoples, and the dissemination of culture for the well-being of humanity and the progress of civilization [emphasis added]'. This touches upon cultural diversity on which the Universal Declaration on Cultural Diversity of 2 November 2001 (UNESCO Doc. 31C/Res.) states in Art. 1: 'As a source of exchange, innovation and creativity, cultural diversity is as necessary for humankind as biodiversity is for nature'.

49 Merryman (1986) and (2005). Set against 'cultural nationalists' with reference to protectionism.

50 See the 2002 Declaration on the Value of the Universal Museum, undersigned by 18 major Western museums. Reproduced in Prott (2009), p. 116 and still available through https://www.hermitagemuseum .org/wps/portal/hermitage/news/news-item/news/1999_2013/hm11_1_93/?lng (accessed 30 July 2020).
} 
one-sidedly favouring the art trade and holding States. ${ }^{51}$ Indeed, such an outlook fails to acknowledge another important interest: the significance of cultural objects to people who identify with them, the social and identity-forming value of cultural objects, and their interests in preserving their culture. The notion of heritage title aims to capture that aspect and addresses the legal bond that people may have with specific cultural objects. As will be seen in the next section, the conventional (UNESCO) regime for the art trade appoints source States as exclusive 'right holders' in this respect, whereas more recent instruments focus on communities and individuals (to be discussed in Sects. 4 and 5).

\section{International Framework for the Art Trade}

Cultural objects can be traded and owned but are also protected as heritage. Viewed through this lens, the regulation of the art trade is about finding a balance between the interests of free circulation and private ownership on the one hand, and heritage interests worthy of protection on the other. What follows is an overview of the international framework for the art trade and how it accounts for heritage interests by linking cultural objects to States.

\subsection{A System of 'National Treasures'}

That framework relies on the 1970 UNESCO Convention, introducing a system of national export licences; the 1995 UNIDROIT Convention, aiming at the harmonisation of private law to implement the principles of the 1970 Convention, and the 'national treasure' exception in both the GATT ${ }^{52}$ and TFEU free trade systems. In broad terms it provides for a system where States designate protected cultural objects that cannot be freely traded (their 'national treasures', 'national heritage' or 'patrimony'), and interstate cooperation after unauthorized export.

Footnote 50 (continued)

Lately, several of these museums have implicitly denounced this position by adopting policies acknowledging the rights of source communities to their lost artefacts.

51 E.g. Bauer (2007), Abungu (2009), Stamatoudi (2011), pp. 19-30; Peters (2020), p. 368. Nafziger: "What the "cultural property internationalists" seem to have in mind, [...], is a generally free trade in cultural heritage unfettered by co-operation among States. At the intergovernmental level, ironically, this interpretation of internationalism turns out to be fundamentally a disguised form of nationalism to protect a country's own collectors and collections. What is more, the rationale for "cultural internationalism" turns out to be essentially commercial.' Nafziger (2008), pp. 202-203.

52 General Agreement on Tariffs and Trade 1994, 1867 UNTS 154, 33 ILM 1154, Art. XX sub. (f). 


\subsubsection{GATT and TFEU}

Cultural objects deserving protection from free circulation are simply defined as 'national treasures' in the text of the GATT and the TFEU. ${ }^{53}$ Article XX (sub. f) of the GATT on General Exceptions allows for national measures that are 'imposed for the protection of national treasures of artistic, historic or archaeological value', that is subject to the requirement 'that such measures are not applied in a manner which would constitute a means of arbitrary or unjustified discrimination between countries [...], or a disguised restriction on international trade'. ${ }^{54}$ Within the European Union Article 36 of the TFEU similarly allows for 'prohibitions or restrictions on imports, exports or goods in transit' insofar as this concerns 'national treasures possessing artistic, historic or archaeological value'. ${ }^{25}$

\subsubsection{UNESCO Convention}

In terms of the 1970 UNESCO Convention such national treasures are defined as 'property, which on religious or secular grounds, is specifically designated by each State as being of importance for archaeology, prehistory, history, literature, art or science'. ${ }^{56}$ Article 4 of the 1970 Convention sets out five categories of objects that can qualify as national cultural heritage. The first two categories bear a clear territorial link: objects created by nationals or others within that territory or objects found within that territory. ${ }^{57}$ The other three categories cover artefacts that were the subject of a 'freely agreed exchange' or acquired 'with the consent of the authorities of the country of origin'. 58

\footnotetext{
${ }^{53} N B$ the official texts of TFEU, Art. 36 vary: in English and French 'national treasures', vs. the Italian and Spanish 'national patrimony' vs. the German 'national cultural property'. Peters (2016), p. 89. The Dutch resembles the 'dry' German version in 'national (artistic, historical or archaeological) property' [in Dutch: 'nationaal artistiek historisch en archeologisch bezit'].

${ }^{54}$ Now part of WTO law. Art. XX. This rule has not been the subject of analysis by a GATT or WTO panel or WTO Appellate Body, so its precise scope remains unclear. Nafziger and Paterson (2014), p. 22. 55 TFEU, Art. 36: 'The provisions of Articles 34 and 35 shall not preclude prohibitions or restrictions on imports, exports or goods in transit justified on grounds of [...]; the protection of national treasures possessing artistic, historic or archaeological value; [...]. Such prohibitions or restrictions shall not, however, constitute a means of arbitrary discrimination or a disguised restriction on trade between Member States'; the notion of this term has been partly defined by two other EU instruments in the area, a Regulation on the export of cultural goods out of the territory of the EU (1992, codified version 2009), and a Directive (1993, recast 2014) on the return of cultural goods illegally exported from the territory of a Member State: these, however, equally refer to the national regime. See also Stamatoudi (2011), pp. $119-120$.

561970 UNESCO Convention, Art. 1, listing 11 types of objects ranging from objects of historical, archaeological, ethnological or artistic interest (e.g. pictures, paintings, drawings and sculpture) to furniture and antiquities of more than 100 years old, rare stamps and archival material.

57 Art. 4: '[...] property which belongs to the following categories forms part of the cultural heritage of each State: (a) cultural property created by the individual or collective genius of nationals of the State concerned, and cultural property of importance to the State concerned created within its territory of that State by foreign nationals or stateless persons resident within such territory; (b) cultural property found within the national territory [emphasis added]'.
}

58 Art. 4, sections (c)-(e). 
The main rule of the 1970 Convention is that the unauthorised transfer of cultural property from the territory of a Member State is illicit, and States should cooperate for their return. What qualifies as national heritage to which return obligations apply after unlawful export, however, is a matter of interpretation. Article 7(b) obliges the return of objects that are documented in an inventory of a public institution. On the other hand, Article 13(d) affirms the indefeasible right of each State Party to this Convention to classify and declare certain cultural property as inalienable which should therefore ipso facto not be exported', and the obligation of other Member States 'to facilitate recovery of such property'. ${ }^{59}$ In other words, States are free to decide what they designate as national cultural heritage that cannot be freely traded.

The Convention is non-self-executing and is non-retroactive: it only applies after both States are party to the Convention and only to the extent that the principles are translated into national law. ${ }^{60}$ This adds up to a system in which the legal status of contested cultural objects depends on the moment they were lost, on the ratification by both States, on the designation in the source country, and on the implementation of the principles in the private law of the destination (or transfer) country. ${ }^{61}$

On the other hand, the 1970 Convention has been widely ratified, ${ }^{62}$ is referred to in many later instruments, ${ }^{63}$ and its main principle that the unauthorized transfer of cultural objects is unlawful has been invoked by national courts as (emerging) public policy also in disputes where the States involved had not acceded to the Convention at the time. ${ }^{64}$

\footnotetext{
591970 UNESCO Convention, Art. 13.

601970 UNESCO Convention, Art. 21.

${ }^{61}$ Various methods of implementation exist, on which Gerstenblith (2020), pp. 31-35.

62140 Member States on 8 July 2020. Amongst these are the major art market States: the US (1983), China (1989), France (1997), the UK (2002), Japan (2002), Switzerland (2003) and Sweden (2003). The Netherlands ratified in 2009, see above n. 5 .

${ }^{63}$ The 2019 EU Import Regulation, introducing a uniform licensing system for cultural objects onto EU territory for objects of a certain age (200 years) confirms the basic principle of the 1970 Convention: (Art. 3) 'The introduction of cultural goods referred to in Part A of the Annex which were removed from the territory of the country where they were created or discovered in breach of the laws and regulations of that country shall be prohibited'. Regulation (EU) 2019/880 of 17 April 2019 on the introduction and the import of cultural goods [2019] OJ L 151/1; For museums, the ICOM Code of Ethics for Museums (under 7.2) presents the 1970 Convention as a minimum standard for museum practice. As the 'ICOM Code of Professional Ethics', the Code was adopted by the 15th General Assembly of the International Council of Museums on 4 November 1986, and was renamed and revised in 2004. See https://icom. museum/wp-content/uploads/2018/07/ICOM-code-En-web.pdf (accessed 30 July 2020).

${ }^{64}$ E.g. in Germany: Allgemeine Versicherungsgesellschaft v. EK, BGHZ 59, 82 (1972); in Switzerland: L. v. Indictment Chamber of the Canton of Geneva (First Public Law Division, 1 April, 1997), both partly reproduced in Prott (2009), pp. 33-36; more examples in Chechi (2014), p. 281, and see the cases discussed in Sect. 5 (n. 146 and n. 173). The Chinese Buddha case, amongst others, underlines that State practice even with regard to recent looting is not uniform.
} 


\subsubsection{UNIDROIT Convention}

Whereas the 1970 Convention relies on cooperation between States, the 1995 UNIDROIT Convention aims to harmonise the private law of Member States to ensure the return of unlawfully removed objects. It has not been widely ratified, however. ${ }^{65}$

The way the Convention classifies claims is interesting: it differentiates between rules for the restitution of stolen objects ${ }^{66}$ - such a claim can be made by any deprived owner-and standards for the return of unlawfully exported cultural objects if these are of 'significant cultural importance to that state'. ${ }^{67}$ Claims based on ownership ('restitution'), in other words, can be distinguished from claims based on heritage title ('return'). In Article 5(3) hints are given as to what types of objects may be of 'significant cultural importance', namely if the removal significantly impairs one or more of the following interests:

(a) the physical preservation of the object or its context,

(b) the integrity of a complex object,

(c) the preservation of scientific or historic information,

(d) traditional or ritual use of the object by indigenous or tribal communities. ${ }^{68}$

In the Convention a choice is made for the common law principle that title cannot be transferred with regard to stolen property: stolen or unlawfully exported cultural objects should be returned, and only a new possessor who 'neither knew or ought reasonably to have known' of the unlawful provenance of an object can claim compensation. ${ }^{69}$ It elaborates on this in Article 4(4):

In determining whether the possessor exercised due diligence, regard shall be had to all the circumstances of the acquisition, including the character of the parties, the price paid, whether the possessor consulted any reasonably accessible register of stolen cultural objects, and any other relevant information and documentation which it could reasonably have obtained, and whether the pos-

\footnotetext{
6548 States have done so, but excluding Western market States such as the US, the UK, Switzerland, Germany, France and the Netherlands (status 12 July 2020).

661995 UNIDROIT Convention, Art. 3, extending the rules to unlawfully excavated cultural objectsusually States vest ownership in archaeological objects in their heritage laws-and private losses, that were not accounted for in the 1970 UNESCO Convention.

${ }^{67} 1995$ UNIDROIT Convention, Art. 5(3), in particular (d) last sentence. The 1991 IDI Basel Resolution proposes a similar definition: artefacts 'most closely linked from the cultural point of view' may be claimed by that country if 'the absence of such property would significantly affect its cultural heritage'.

68 This listing is obviously open to a myriad of interpretations. Nevertheless, the general idea is 'cultural significance'. The separate mentioning of the interests of communities in (d) is noteworthy, as this implicates a step away from the paradigm of one national culture underlying the 1970 UNESCO Convention that has in its preamble: 'Considering that cultural property constitutes one of the basic elements of civilization and national culture, [...]'(emphasis added).

${ }^{69} 1995$ UNIDROIT Convention, Art. 4(1): 'The possessor of a stolen cultural object required to return it shall be entitled, at the time of its restitution, to payment of fair and reasonable compensation provided that the possessor neither knew nor ought reasonably to have known that the object was stolen and can prove that it exercised due diligence when acquiring the object'. Such right to compensation should be seen as a concession to the civil law countries that tend to protect good faith new possessors.
} 
sessor consulted accessible agencies or took any other step that a reasonable person would have taken in the circumstances.

These due diligence standards are repeated in other legal instruments and national laws of countries that have not acceded to the Convention, and thus have gained importance in their own right. ${ }^{70}$ Furthermore, the Convention sets a limitation period for filing a claim of three years after the location and possessor of the object are known, with a maximum of fifty years after the theft. ${ }^{71}$ Objects forming an integral part of an identified monument or archaeological site, or belonging to a public collection, and sacred or communally important cultural objects used by tribal or indigenous communities, are under enhanced protection. ${ }^{72}$

\subsection{Rules for the Art Trade in Practice}

The conventional regime thus aims to control the movement of cultural objects. Since market countries have only recently started implementing the 1970 UNESCO Convention - and do so in a number of different ways-, and the 1995 UNIDROIT Convention has not been widely ratified, the fragmented situation continues. ${ }^{73}$ As Lixinski observes: 'One of the problems of the licit market is that, because it is largely unregulated by international law [...] it ends up regulated by the private sphere'. ${ }^{74}$

To counter legal insecurity, two rules have surfaced in practice: new possessors need to ascertain that objects have no 'unlawful provenance' (due diligence standards); and the second rule takes a practical approach to the ambiguous question of what exactly constitutes 'unlawful provenance'.

\subsubsection{Due Diligence Standards}

The importance of due diligence standards and provenance research for the art market as introduced in the 1995 UNIDROIT Convention is confirmed in many later legal instruments. ${ }^{75}$ The 2017 UN Security Council Resolution, for example, requests States to take 'appropriate steps to prevent and counter the illicit trade and

\footnotetext{
70 E.g. the Netherlands has not ratified the 1995 UNIDROIT Convention, however did include this element in its Heritage Act of 9 December 2015 (Staatsblad 2016, no. 14).

711995 UNIDROIT Convention, Art. 3.

721995 UNIDROIT Convention, Art. 3, paras. (4), (7) and (8). A maximum of 75 years can be set by States. This means that cases that-for whatever reason-take long to surface such as Nazi-looted art or colonial takings, would not be covered. This is the downside of an ownership approach.

73 The "patchwork quilt of ratifications and implementation of the 1970 UNESCO Convention and of the 1995 UNIDROIT Convention and the limited provisions of the 1954 Hague Convention with respect to stolen or looted cultural objects translate into an International treaty regime that is weak in controlling the movement of illegally obtained cultural objects'. Gerstenblith (2020), p. 37.

74 Lixinski (2019), p. 132.

75 Above, n. 70, and the UNESCO International Code of Ethics for Dealers in Cultural Property, UNESCO Doc. CLT/CH/INS-06/ 25 REV, basically stating that dealers shall not deal in objects with an 'unlawful' provenance.
} 
trafficking in cultural property [...] including by prohibiting cross-border trade in such illicit items where states have a reasonable suspicion that the items originate from a context of armed conflict, [...] and which lack clearly documented and certified provenance, thereby allowing for their eventual safe return'. ${ }^{76}$ The Resolution calls upon States to adopt measures 'Engaging museums, relevant business associations and antiquities markets participants on standards of provenance documentation, differentiated due diligence and all measures to prevent the trade of stolen or illegally traded cultural property'. ${ }^{77}$

Beyond the context of armed conflict, the new EU Import Regulation similarly relies on the importers' documentation that should support the lawful ownership history (provenance) before an object can be imported. ${ }^{78}$ Moreover, the 2017 Council of Europe Nicosia Convention, which has yet to enter into force, replicates these due diligence standards. ${ }^{79}$ State parties should take measures to ensure that the acquisition or 'placing on the market' of stolen or unlawfully transferred cultural property is a criminal offence, not only if the person knowingly acquires such objects but 'also in the case of a person who should have known of the cultural property's unlawful provenance if he or she had exercised due care'. ${ }^{80}$

Such regulations clearly underscore the importance of provenance research for the international art world. Buyers, dealers, auction houses and museums must assure themselves not only of the authenticity of an object (is it real?) but also of its provenance (who were the previous owners and was it lawfully acquired?). At the same time, this implies that artefacts with an incomplete provenance will surface as 'tainted', whereas the question of what is exactly '(un)lawful' is anything but clear. ${ }^{81}$

\subsubsection{The 1970 Watershed Rule on Provenance}

What, exactly, is an 'unlawful provenance' is a key question in regulating the art trade. The answer, however, depends on the perspective one takes: unlawful according to what law? As discussed, national laws on the transfer of ownership vary widely in time and place, while international rules are neither retroactive nor clearly defined. In this regard, the ' 1970 watershed rule' has surfaced as a 'proxy

\footnotetext{
76 UNSC Res. S/RES/2347 (2017), para. 8. Emphasis added.

77 Ibid., under 17(g). Emphasis added.

78 EU Regulation $2019 / 880$ of 17 April 2019 'on the introduction and the import of cultural goods' [2019] OJ L 151/1.

79 Council of Europe Convention on Offences relating to Cultural Property, adopted 3 May 2017, CETS No. 221. The Convention aims to prevent and combat the illicit trafficking and destruction of cultural property, and falls within the Council of Europe's action to fight terrorism and organised crime. It is open to non-members (Mexico is one of the two ratifying States). NB On 28 October 2019, 10 States had signed and 2 had ratified/acceded, thus it has not yet entered into force.

80 Ibid., Arts. 7 and 8.

81 Problematic is that no publicly managed and accessible database for stolen artefacts exists, whereas some databases that do exist solely focus on provenance between 1933-1945. See also Campfens (2019b).
} 
to legality' ${ }^{82}$ It is a touchstone used by auction houses, the art trade and museums, implying that artefacts should have a documented provenance as of the entry into force of the 1970 UNESCO Convention (24 April 1972), either as being outside the country of origin before that date or otherwise with an export licence. ${ }^{83}$ This rule is confirmed in soft and hard law instruments. ${ }^{84}$ The new EU Import Regulation, for example, allows for the importation of cultural objects without an export licence as long as the object was outside its source country before 24 April $1972 .{ }^{85}$

The 1970 watershed rule (which in fact is 1972) operates, in other words, as a time lock for a new international order of controlled trade. In spite of its apparent attraction (legal security), such a time lock has a serious downside. Source countries may not be able to prove that a specific object was still on their territory: cultural objects are not always documented in an inventory-e.g. freshly (illicitly) excavated archaeological objects by definition are not documented and (sacred) items in use by a community may not be listed either. Besides, objects unlawfully taken longer ago may be more important from a heritage perspective, although these are lawfully owned somewhere else. ${ }^{86}$ At the same time, provenance research has not always been an issue and many artefacts lack information on their ownership history: this does not necessarily mean that an object was unlawfully taken. Leaving such nuances aside, one noticeable effect of this rule is that artefacts offered on the market remarkably often are presented with a provenance in terms of a "private (Western) collection' followed by a date before $1970 .{ }^{87}$ These blind spots will be further addressed in the next section.

\section{Blind Spots and the Rise of Soft Law}

To curb illicit trade, the 1970 UNESCO Convention aims to prevent the unauthorized export of cultural objects and preservation in situ. That, however, does not solve title issues over cultural objects that left their original setting at one point in their existence. Contesting parties may be States, but also communities or private individuals. This is an important blind spot in the legal regime for the art trade, that has

\footnotetext{
82 To cite Gerstenblith (2013), p. 153. See also Négri (2015), p. 10.

83 The 1970 UNESCO Convention entered into force on 24 April 1972; this time lock is also used as simply 'before or after 1970'.

${ }^{84}$ E.g., the 2013 Guidelines on the Acquisition of Archaeological Material and Ancient Art of the US Association of Art Museum Directors (AAMD), under 'E', prescribe that 'Member museums normally should not acquire a Work unless provenance research substantiates that the Work was outside its country of probable modern discovery before 1970 or was legally exported from its probable country of modern discovery after 1970'. See: https://aamd.org/sites/default/files/document/AAMD\%20Guidelines\%20201 3.pdf (accessed 30 July 2020).

85 Above n. 63.

${ }^{86}$ In jurisdictions allowing for the transfer of title which will be unlawful from the perspective of source communities' laws or international law (above n. 15 and the accompanying text).

87 Observation by the author. Cf., e.g., Lixinski (2019), p. 132: 'The black market in antiquities exploits this loophole through creating mechanisms to prove that the objects left the territories of the states in question before the Convention's entry into force, thus laundering the cultural artefacts'. See also Campbell (2013).
} 
caused an increase in soft law to 'mend' gaps: a sign of changing morality and the need for new rules. These points will be further explored hereunder.

\subsection{Nationality?}

A question that arises in dispute resolution is what 'national cultural heritage' in the 1970 UNESCO Convention - and 'national treasure' in the GATT and TFEUexactly means in terms of entitlement. It gives the impression that States are exclusive right holders (owners) of cultural objects. What, however, is the basis for such title?

As mentioned in the preceding section, the 1970 UNESCO Convention is not clear on this point and essentially leaves it up to States to decide what they designate as their cultural heritage. In practice, this is done either according to a model of listing a limited number of items of national and/or outstanding importance (the 'liberal' model from the point of view of trade), or according to a model under which broad categories of objects are appointed in blanket legislation (the 'retentionist' model from the point of view of the trade). ${ }^{88}$

In that respect, States may also designate cultural objects to underline a territorial claim, such as the Russian law that, since 2015, considers Crimean collections to be Russian patrimony. ${ }^{89}$ Ongoing litigation in the Netherlands over archaeological objects that were on loan in Amsterdam from Crimea at the time of the Russian annexation in 2014 confirms that conflicting claims to the same 'national treasure' occur. The Ukrainian State, on the one side, claims that these artefacts belong to its national patrimony and should be sent to Kiev. On the other side, the Crimean museums claim that it concerns cultural heritage of the Crimean people, having been there since the excavation, and should be returned to them. ${ }^{90}$ In the meantime, the contested objects are also designated as Russian cultural property.

A model linking cultural objects to States without clear standards as to what qualifies as such causes tensions. The Institut de Droit international advised in this respect that a 'country of origin' should be understood to be the country with which the object is 'most closely linked from a cultural point of view'. 91 The 1995 UNIDROIT Convention similarly gives as a criterion 'significant cultural importance'

\footnotetext{
${ }^{88}$ As a rule of thumb: culturally rich 'source countries' apply the second form-aiming at wide protection-and importing 'market countries' apply the first. For a discussion on designation as 'national treasures', see above n. 45 and the accompanying text.

89 Russian Federal Law (Feb. 12, 2015) No. 9-FZ 'On regulation of relations in the matter of culture and tourism as related to the annexation of the Republic of Crimea to the Russian Federation [...]'. See: https ://cis-legislation.com/document.fwx?rgn=73149 (accessed 5 May 2020).

90 In 2016, the Amsterdam District Court honoured the claim by Ukraine on the basis of the 1970 UNESCO Convention, Rechtbank Amsterdam, Judgment of 14 December 2016, Case No. C/13/577586/HA ZA 14-1179, ECLI:NL:RBAMS:2016:8264. The verdict is subject to an appeal at the time of writing (Spring 2020). The case is discussed in Campfens (2017).

911991 IDI Basel Resolution', above n. 19.
} 
as a ground for return requests. ${ }^{92}$ Lastly, the (more recent) 2001 UNESCO Convention for Underwater Cultural Heritage may serve as inspiration where it introduces a 'verifiable link', based on identification, as a basis for responsibilities and limited rights (but not as a basis for exclusive rights). ${ }^{93}$ In sum, a verifiable cultural link between people and objects, that may be called 'heritage title', should underlie a claim to national heritage.

Whereas archaeological finds and ethnological objects are clearly linked to a territory and its people_-but not per se to a nation State after a change of borders-, artefacts that were destined for the market will not easily pass this test. This is reflected in the US case Jennerette $v$. Vichy. ${ }^{94}$ In this case the court denied a claim by the Italian government to a Matisse painting that was exported in violation of Italy's export laws (but obviously lacks a strong cultural link with Italy), which contrasts with judicial practice in the US that tends to award claims by source countries to antiquities. ${ }^{95}$

A more correct interpretation of 'nationality' appears therefore that this primarily serves as a means to allocate responsibilities. States should not be seen as exclusive and absolute 'right holders' to cultural heritage, but act as stewards of the public interest and, in that regard, take measures to preserve cultural objects and make these accessible (the notion of the heritage of mankind). This also means that restrictions on the transfer of cultural objects in national laws to control the market should ideally not only regulate the export of cultural objects of local importance, but also the import of objects that are important to other people. ${ }^{96}$ On the other hand, if a State claims entitlement to an object as its 'national heritage' after it left its territory, it acts in another capacity, namely as a right holder to heritage title. It may do so on behalf of the people on its territory and such a claim should depend on a verifiable and continuing cultural link.

\subsection{Sub-State Right Holders}

The UNESCO framework is an interstate affair: only national States are treated as 'right holders' to cultural objects, as seen above. Although the idea of one 'national' culture may reflect reality in a few States, nationality as a criterion for entitlement is insufficient. This mostly becomes relevant when communities or individuals do not (any longer) feel represented by a specific State. The Crimean case discussed above is a clear example, but this may also surface in cases that concern Nazi-looted art. Such disputes, not seldomly, concern artefacts lost by the hands of authorities of States of which the families were once nationals. The Altmann case (depicted in the Hollywood movie 'Lady in Gold'), that deals with paintings by the Austrian painter

\footnotetext{
921995 UNIDROIT Convention, Art. 5(3); see above nn. 67 and 68.

93 Above n. 33 and Dromgoole (2013), p. 127.

94 Jennerette v. Vichy, 693 F2d 259, 267 (2d Cir. 1982).

95 A well-known example of a claim by a source country to antiquities, United States v. Schultz, $178 \mathrm{~F}$. Supp. 2d445 (SDNY, 3 January 2002).

96 For the European Union, therefore, the introduction of the 2019 Import Regulation is important (see above n. 78).
} 
Gustav Klimt that were protected as national Austrian patrimony, may serve as an illustration. ${ }^{97}$ The paintings were claimed by a US citizen, Maria Altmann, the niece and heir to the Austrian Jewish collector who lost the works due to Nazi persecution. After attempts to regain the works in Austria failed, litigation in the US was initiated, where the Supreme Court held that it had jurisdiction over the case as the loss was considered a violation of fundamental rights. ${ }^{98}$ After this victory, international arbitration was set up that resulted in the restitution of the paintings to Altmann. In this particular case, in other words, the interests of the persecuted and dispossessed family outweighed the interests of a national State in preserving its national heritage. Similarly, in a French case concerning a Mokomokai (a mummified tattooed head of a Maori) held in a museum in Rouen, after the initial denial of the claim for repatriation because the 'museum piece' was protected under French patrimony laws, a special law was enacted to enable repatriation and the eventual ritual burial by the Maori. ${ }^{99}$ Also here, the interests of the French State in keeping its "national heritage'(public collections) were outweighed by the interests of the indigenous community. The prevalence of such interests was confirmed by the adoption of the UNDRIP, to be discussed in the next section. ${ }^{100}$

For the category of Nazi-looted art the 1998 Washington Conference Principles on Nazi-Confiscated Art form the basis for a widespread international practice of returns and settlements. ${ }^{101}$ It concerns a set of principles supported by over forty States and other stakeholders, stating the right of families of deprived former owners to a 'fair and just solution' with regard to Nazi-looted artefacts. ${ }^{102}$ Also for other categories soft law instruments focus on sub-state right holders. In this regard, the ICOM Ethical Code for Museums_-an important instrument of self-regulation for

\footnotetext{
97 Maria V. Altmann v. Republic of Austria et al., 142 F. Supp. 2 d 1187 (CD Cal. 2001); Maria V. Altmann v. Republic of Austria et al., 317 F. 3d 954 (9th Cir. 2002), as amended, 327 F. 3d 1246 (2003); Republic of Austria et al. v. Maria V. Altmann, 541 US 677 (US 2004). For an overview, Renold et al. (2012).

98 In spite of the immunity provided by the Foreign Sovereign Immunity Act (FSIA), Nazi confiscations fall under an exception that 'abrogates sovereign immunity in any case where rights in property taken in violation of international law are in issue and that property [...] is owned or operated by an agency or instrumentality of the foreign state and that agency or instrumentality is engaged in a commercial activity in the United States'. Explained in David L. de Csepel et al. v. Republic of Hungary et al., No. 10-1261 (ESH), Memorandum Opinion, US Dist. (C.D. Columbia, 14 March 2016), at p. 28 (emphasis added).

99 For a discussion see Lenzerini (2017), p. 339.

100 United Nations Declaration on the Rights of Indigenous Peoples, GA Res. 61/295, UN GAOR, UN Doc. A/RES/61/295, 13 September 2007 (UNDRIP). The introduction of 'the traditional or ritual use by indigenous or tribal communities' as a separate ground in Art. 5(3) of the 1995 UNIDROIT Convention is also an acknowledgement that national States should not be seen as sole right holders.

101 Washington Conference Principles on Nazi-Confiscated Art, in Bindenagel (1999).

102 This is contrasted by efforts to arrange this field by UNESCO in the traditional interstate way. See UNESCO, Draft of the Declaration of Principles Relating to Cultural Objects Displaced in Connection with the Second World War (2009), 35 C/24. After years of negotiations the UNESCO Declaration was not adopted and never heard of again, perhaps unsurprisingly given the historical background of the looting. It relied on a traditional intergovernmental model and objects should have been claimed by the country from where these were lost on behalf of the deprived owners. The inefficiency of such a model where individual claimants would have to rely on cooperation with the governments of States that were responsible for the dispossession and persecution in the first place, may be obvious.
} 
museums around the world-prioritizes cooperation and dialogue over 'action on a governmental or political level' where return requests are concerned. ${ }^{103}$

Whilst the binding force and practical follow-up of these instruments vary, they signal a preference for the sub-state level over dealing with claims on the interstate level.

\subsection{Non-Retroactive?}

The field of Nazi-looted art also highlights the most poignant blind spot of the conventional framework: that it does not regulate earlier losses. ${ }^{104}$ Losses by persecuted Jewish families obviously occurred long before the 1970 UNESCO Convention and are 'stale' under (most) national private laws due to limitation periods for claims, or the acquired ownership rights of new possessors. ${ }^{105}$ Nevertheless, since the end of the 1990s such claims have been widely supported by States and participants in the art world, albeit often as a matter of 'morality' through extralegal procedures. In this regard, a discrepancy has emerged between European and US jurisdictions-where most art cases occur due to the scale of the art market and where the adage that a thief cannot transfer good title is inherent in the legal system and such cases can be litigated on their merits. ${ }^{106}$ Given the international character of the art market, this discrepancy leads to forum-shopping and legal insecurity. As will be discussed in the next section, a human rights approach and the notion of heritage title may enable access to justice also for such cases.

Increasingly, also countries or communities that have been victims of looting and illicit export in the past reclaim their heritage irrespective of the 1970 threshold. ${ }^{107}$ Litigation in the US between the Greek Government and Sotheby's over the (intended) auction of an eighth century BC bronze statuette of a horse-that was part of a Swiss collection in 1967-is an example. ${ }^{108}$ The Greek Government statement was that 'the owners of stolen property and auction houses cannot trade objects belonging to a country's cultural heritage'. ${ }^{109}$ In its June 2020 ruling the US Court of Appeals denied Sotheby's claim for a declaratory judgment that the bronze horse was 'acquired lawfully and in good faith', cutting short the expectations of

\footnotetext{
103 ICOM Code of Ethics for Museums (above, n. 63), Principle 6.2.

104 The 1970 UNESCO Convention, the 1995 UNIDROIT Convention, as well the 1991 IDI Basel Declaration provide for the proactive application of norms (see above Sect. 3). In terms of the last, "to all future cases where a work of art has been stolen or otherwise taken away illegally from its owner or holder, or illegally exported'. Emphasis added.

105 After the Second World War, most European countries enacted special restitution laws to restore the rights of victims of Nazi persecution with regard to their lost possessions; however, due to limitation periods in such laws these (mostly) lost their importance. See Campfens (2018).

106 Resulting in a situation where many European restitution claims are brought before American courts. Campfens (2017) and (2019b).

107 These countries include, e.g., China, Turkey, Mexico, Columbia, Egypt and India.

108 See Chrysopoulos (2019).

109 Ibid.
} 
the 1970 threshold to provide legal security. ${ }^{110}$ Another example that underscores the confusion in this field can be found in the Ukrainian heritage law that specifically includes, as national patrimony 'subject to return', works that were pillaged during past wars. ${ }^{111}$ Also in China artefacts pillaged in the past are considered to be national treasures that should not be traded. ${ }^{112}$ Accordingly, in 2018 the Chinese government objected to the auction in the UK of a bronze vessel that was looted from the Old Summer Palace in 1860 by Anglo-French forces. While the auction eventually went ahead, the vessel was donated to China, to feature in a 2019 exhibition dedicated to 'reclaimed national treasures from abroad' ${ }^{113}$

This trend may be seen as the result of a failure of the international community to address cultural losses before 1970. During the negotiations of the 1970 UNESCO Convention the return of cultural objects lost as a result of (post-)colonial looting practices had clearly been at stake for formerly colonised States. Yet, the issue was not resolved at the time but was left to bilateral negotiations. ${ }^{114}$ To accommodate such negotiations, in 1978, the Intergovernmental Committee for Promoting the Return of Cultural Property to Its Countries of Origin or Its Restitution in Case of Illicit Appropriations (ICPRCP) was established by UNESCO. ${ }^{115}$ The political setting of this committee, however, has proven unfavourable to actually solve disputes.

Recent developments underscore that denying victims of past plundering access to justice does not solve the problem. Over time, cultural objects may maintain —or even gain - their symbolic value, especially if they were lost as a result of historical injustices such as colonial oppression or racial persecution. Although such claims may lack legal force from a private law perspective, it should be born in mind that

\footnotetext{
110 Barnet and Sotheby's v. Hellenic Republic, No. 19-2171-cv (US Court of Appeals for the $2^{\text {nd }}$ Circuit, 9 June 2020), available at https://www.govinfo.gov/content/pkg/USCOURTS-ca2-19-02171/pdf/USCOU RTS-ca2-19-02171-0.pdf (accessed 27 July 2020). See Brown (2020).

111 Art. 3 of the 1999 Law of Ukraine 'On Exportation, importation and Return of Cultural Values' includes as 'cultural values of Ukraine' lists 'Cultural values, evacuated from the territory of Ukraine during wars, armed conflicts and not being returned', that, according to Art. 4, are subject to a return to Ukraine. Official Bulletin (Vidomosti) of the Verhovna Rada (BBP), 1999, No. 48, p. 405. Translation kindly provided by I. Tarsis, Managing Director Center for Art Law, NY.

112 The Cultural Relics Protection Law of the People's Republic of China, entered into force in 1982, amended in 2017 [CLI.1.304324(EN)], provides in Art. 5 for ownership by the State of five very broadly formulated categories of (Chinese) 'cultural relics'. Chinese scholars have argued for amendments to include 'lost cultural relics' as a legal basis for return claims. See Zhen (2009), Tao (2009), both in Chinese. Information and translation kindly provided by Dr. Yue Zhang, visiting fellow at the Max Planck Institute for Comparative Public Law and International Law, Heidelberg, Germany.

113 Global Times (2018).

114 Prott (2009), p. 13. A Chinese proposal to include a provision on older losses in the 1970 UNESCO Convention was not accepted by Western States.

115 Statutes of the ICPRCP, adopted by $20 \mathrm{C} /$ Resolution $4 / 7.6 / 5$ of the 20th session of the General Conference of UNESCO, Paris, 24 October-28 November 1987, amended in October 2005. See https:// unesdoc.unesco.org/ark:/48223/pf0000145960?posInSet=1\&queryId=1e02e2a2-fd0d-46bd-8ebe77ad27eb0433 (accessed 13 August 2020).
} 
norms prohibiting plundering were in existence long before the entry into force of the 1970 UNESCO Convention. ${ }^{116}$

Meanwhile, international practice and the legal argumentation used in claims signal a new paradigm. The Chinese statement in the case discussed above, for example, refers to the 'cultural rights of the Chinese people', while French President Macron in his famous 2017 speech announcing the return of African artefacts, refers to the right of Africans to access their own culture. ${ }^{117}$ Likewise, a 2019 German government policy instrument, facilitating the return of colonial takings by German museums, provides as a rationale that 'all people should have the possibility to access their rich material culture [...] to connect with it and to pass it on to future generations'. ${ }^{118}$ Such quotes refer, in other words, to the (human) right of access to one's own culture. The question of how a human rights approach could help regulate this field will be further discussed hereafter.

\section{A Human Rights Approach and Heritage Title}

As has emerged in the preceding sections, neither regular ownership law nor the conventional regime for the art trade are particularly suited to solve title issues with regard to contested cultural objects. In the meantime, the proliferation of soft law instruments indicate that new standards are needed. In that regard, a human rights approach deserves further examination. The apparent advantages of such an approach are that human rights law is particularly equipped to address heritage and identity values; that human rights are of a universal nature, and penetrate and shape how private law is being interpreted and adjudicated. Which human rights notions can exactly be used, how these can inform the contents of heritage title, and how such title can be made operational will be addressed next. As the law is evolving, this should be read as an invitation for further debate on a human rights-inspired concept of cultural property.

A paragraph on the increasing interrelation between cultural heritage and human rights law will serve as an introduction.

\footnotetext{
116 This is of importance for booty taken during armed conflict. E.g. Siehr (1993), p. 131: 'It has now been well established that for 150 years any kind of pillage, capture or acquisition of works of art as booty during times of war, armistice or occupation is prohibited by public international law'. For a thorough evaluation of the binding status of the obligation to return colonial booty Zhang (2018). See also Campfens (2019a), pp. 88-91.

117 Emmanuel Macron, Speech at the University of Ouagadougou (Ouagadougou, 28 November 2017), https://www.elysee.fr/emmanuel-macron/2017/11/28/discours-demmanuel-macron-a-luniversite-deouagadougou (accessed 20 April 2020).

118 'Erste Eckpunkte Zum Umgang Mit Sammlungsgut Aus Kolonialen Kontexten' (2019), https://www. kmk.org/fileadmin/pdf/PresseUndAktuelles/2019/2019-03-25_Erste-Eckpunkte-Sammlungsgut-kolon iale-Kontexte_final.pdf (accessed 23 July 2020).
} 


\subsection{Humanization of Cultural Heritage Law}

International cultural heritage law has rapidly expanded and evolved over the last decades. Regulations may be binding or non-binding, but a common denominator is the increased attention for the intangible and social aspects of cultural heritage, away from an understanding solely in terms of exclusive rights or the intrinsic value of objects for mankind at large, and a shift in focus from State interests to the interest of communities and individuals: the 'humanization' of cultural heritage law. ${ }^{119}$

The increased attention of the Human Rights Council and the Security Council in resolutions on cultural heritage protection, voicing concerns over destruction, looting and illicit trade, highlights not only the scale and urgency of the problemsmostly but not only in conflict areas-, but also the impact this has on the affected communities in terms of the realization of their human (cultural) rights. ${ }^{120}$ In this sense, in a 2007 resolution that is dedicated to the protection of cultural heritage, the Human Rights Council affirms that 'cultural heritage is an important component of the cultural identity of communities, groups and individuals, and of social cohesion, so that its intentional destruction may have adverse consequences on human dignity and human rights'. ${ }^{121}$ As Hausler observes, this initiated a 'human rightsbased approach' to cultural heritage protection developed by the Council in subsequent resolutions, in which protection is linked to the right of everyone to take part in cultural life. ${ }^{122}$ Apart from concerns about the act of looting and the destruction this causes, the Council also addresses the illicit trade and return of looted objects. In this regard, it 'invites' States to adopt measures at the national level. ${ }^{123}$

On the European level, the 2005 Council of Europe Framework Convention on the Value of Cultural Heritage for Society (Faro Convention) also clearly illustrates this 'humanization'. The Convention does not create enforceable rights, but rather voices policy aims for governments, opening the door to a new understanding of cultural heritage and its title holders. ${ }^{124}$ It defines cultural heritage as 'a group of resources inherited from the past which people identify, independently of ownership, as a reflection and expression of their constantly evolving values, beliefs, knowledge

\footnotetext{
119 See, e.g. Francioni (2011), p. 14: '[B]ringing the focus from the protection of the cultural object to the social structures and cultural processes that have created and developed the "intangible" heritage. States remain the contracting parties to the Convention but the substantive addressees are the cultural communities and human groups, including minorities, whose cultural traditions are the real object of the safeguarding under international law'.

120 Above nn. 34, 35, and 39. See also Hausler (2020).

${ }^{121}$ UNHRC, Res. 6/11 on Protection of Cultural Heritage as an Important Component of the Promotion and Protection of Cultural Rights, UN Doc. A/HRC/RES/6/11 (28 September 2007), Preamble.

122 Hausler (2020), pp. 207-213.

${ }^{123}$ UNHRC, Res. 33/20 on Cultural rights and the protection of cultural heritage, UN Doc. A/HRC/ RES/33/20 (6 October 2016), at p. 4; repeated in UNHRC Res 37/17 on Cultural rights and the protection of cultural heritage, UN Doc. A/HRC/RES/37/17 (9 April 2018), at p. 4: 'Calls for enhanced international cooperation in preventing and combating the organized looting, smuggling and theft of and illicit trafficking in cultural objects and in restoring stolen, looted or trafficked cultural property to its countries of origin, and invites States to take measures in this regard at the national level'.

${ }^{124}$ E.g., the Netherlands is not yet a signatory, but it has introduced the Faro Convention's definition of cultural heritage in Art. 1(1) of its new Heritage Act (Relating to the Combining and Amendment of Rules Regarding Cultural Heritage) of 2015.
} 
and traditions'. ${ }^{125}$ As 'right holders' it introduces the notion of a 'heritage community', defined as 'people who value specific aspects of cultural heritage which they wish, within the framework of public action, to sustain and transmit to future generations'. ${ }^{126}$ In as far as it concerns competing claims to heritage, the Faro Convention proposes 'equitable solutions'-similar to the norm in soft law instruments. In this regard, the Convention calls on States to: (a) encourage reflection on the ethics and methods of presentation of the cultural heritage and respect for diversity of interpretations; and (b) establish processes for conciliation to deal equitably with situations where contradictory values are placed on the same cultural heritage by different communities. ${ }^{127}$

Given this shift in thinking about values that should underly cultural heritage policies_-and thus entitlement to cultural object-, the next question is which binding human rights norms could further inform heritage title.

\subsection{A Human Right to Cultural Property?}

\subsubsection{The Right of Access to (One's Own) Culture}

Of key importance in this respect is the evolution of the right of 'access to one's culture', as it developed from the right to culture in the International Covenant on Economic, Social and Cultural Rights (ICESCR). ${ }^{128}$ According General Comment 21 that deals with the 'right of everyone to take part in cultural life' in Article 15(1) (a) of the ICESCR, this has come to include 'access to cultural goods'. ${ }^{129}$ Furthermore, the 2011 report of the independent expert in the field of cultural rights, Farida Shaheed, sheds further light on the content of this right, where she concludes that:

The right of access to and enjoyment of cultural heritage forms part of international human rights law, finding its legal basis, in particular, in the right to take part in cultural life, the right of members of minorities to enjoy their own culture, and the right of indigenous peoples to self-determination and to maintain, control, protect and develop cultural heritage. ${ }^{130}$

Similar to the concept of 'heritage communities' in the Faro Convention, Shaheed notes that 'varying degrees of access and enjoyment may be recognized, taking into

\footnotetext{
125 Framework Convention on the Value of Cultural Heritage for Society (adopted 27 October 2005), CETS No. 199 (Faro Convention) (emphasis added), Art. 6.

126 Faro Convention, Art. 2(b).

127 Faro Convention, Art. 7(b).

128 Art. 15 of International Covenant on Economic, Social and Cultural Rights (adopted 16 December 1966), 993 UNTS 3 (ICESCR). See also Art. 27 of the UDHR.

${ }^{129}$ Committee on Economic, Social and Cultural Rights, General Comment No. 21 (2009), UN Doc. E/C.12/GC/21, under 'Normative content', para. 7.

${ }^{130}$ Human Rights Council, Report of the independent expert in the field of cultural rights, Farida Shaheed, 21 March 2011, UN Doc. A/HRC/17/38, p. 20, para. 78.
} 
consideration the diverse interests of individuals and groups according to their relationship with specific cultural heritages' ${ }^{131}$ She notes the following hierarchy:

- 'source communities', people who are keeping cultural heritage alive and/or have taken responsibility for it;

- individuals and communities [...] who consider the cultural heritage in question an integral part of the life of the community, but may not be actively involved in its maintenance;

- scientists and artists; and

- members of the general public accessing the cultural heritage of others.

Although this list is of a general nature and not per se aimed at lost cultural objects, this hierarchy underscores that, at times, there may be more than one right holder, and that the weighing of interests should depend on the specific social function of cultural objects. This resurfaces in the UNDRIP and NAGPRA ${ }^{132}$ models discussed further on. ${ }^{133}$

\subsubsection{The Right to (Cultural) Property}

Heritage title may also be addressed from the perspective of the (human) right to property, given that this protection is not only aimed at the right of ownership of things. ${ }^{134}$ Of course, if owners lose their artefact as a result of unjustified expropriation, that loss in itself may constitute a violation of the human right to property. ${ }^{135}$ Beyond the loss of ownership, however, other interests may qualify as 'property' in a human rights' sense. For example, the Inter-American Court of Human Rights has on several occasions recognised pre-existing collective property rights by indigenous peoples to ancestral lands (owned by others) within the scope of the right to property (and political rights). ${ }^{136}$

According to the the European Court of Human Rights (ECtHR) 'the notion of "possessions" in Article 1 of the First Protocol indeed has an autonomous meaning which is not limited to ownership of physical goods: certain other rights and

\footnotetext{
131 Ibid., p. 16, para. 62.

132 US Native American Graves Protection and Repatriation Act of 16 November 1990 (25 USC paras. 3001-13) (NAGPRA).

133 Janet Blake observes that if we wish to ensure a human rights-based approach to cultural heritage protection, local and cultural communities have an overriding interest, over and above national interests, because of their connection with their heritage. Blake (2015), p. 289.

134 Above n. 22.

135 Jayme (2015) argues that the Altmann case, litigated in the US, proves the retroactive effect of the human right to property to losses predating human rights instruments (in that case, a loss in the 1940s). In a common law system, this may be easier than in civil law systems.

136 E.g. Kaliña and Lokono Peoples v. Suriname, Merits, Reparations and Costs, Inter-Am. Ct HR, Series C, No. 309, 25 November 2015. Furthermore, in the Charter of Fundamental Rights of the European Union (2000/C 364/01) the protection of possessions also covers intellectual property (Art. 17(2)).
} 
interest constituting assets can also be regarded as "property rights". ${ }^{137}$ In that spirit, although the European Convention on Human Rights does not include a right to culture, rights to cultural objects (beyond ownership) have been addressed from the perspective of the right to property in Article 1 of the First Protocol by the ECtHR. ${ }^{138}$ An example is the 2012 Nowakowski case in which the ECtHR acknowledged the 'sentimental' value of a cultural object to a certain person-in this case, a collection of firearms in private property that had been confiscated by Polish authorities - and gave that preference over other interests. ${ }^{139}$

Whether (human rights) courts would be ready to acknowledge an infringement of human rights with regard to cultural property lost in the (far) past, remains to be seen. In 2016 the ECtHR rejected the application brought by an Athenian association with regard to the Parthenon Marbles-important sculptures from the Acropolis in Athens that the British Ambassador to the Ottoman Empire, Lord Elgin, hacked off and took with him to London at the beginning of the nineteenth century-, due to the time that had passed since the loss. ${ }^{140}$ The court held that the claim was inadmissible, ratione tempore as well as ratione materiae, as none of the invoked articles 'would give rise to any right for an association in the position of the applicant to have the Marbles returned to Greece or to have the UK engage in international mediation'. ${ }^{141}$ Nevertheless, given that morality in this field is rapidly changingwhether it concerns present-day looting, Nazi-looted art or colonial losses-, this path should not be dismissed too soon.

\subsubsection{Other Human Rights Norms}

Potentially, many other human rights qualify to inform heritage title, such as the freedom of religion ${ }^{142}$; respect for private and family life ${ }^{143}$; the rights of minorities to enjoy their own culture, ${ }^{144}$ or the right to self-determination. ${ }^{145}$

This last right has been invoked and accepted in a 2008 Italian ruling dealing with a sculpture (the 'Venus of Cyrene') taken by Italian colonial agents from what

\footnotetext{
137 Gasus Dosier- under Foerdertechnik v. the Netherlands, no. 15375/89, ECtHR 23 February 1995, Series A vol. 306-B, § 53. See Poeger and Stolker (2000).

138 European Convention for the Protection of Human Rights and Fundamental Freedoms (adopted 4 November 1950), 213 UNTS 222 (ECHR). In the case law, rights that may fall under the notion of "cultural rights' have been recognized. Jakubowski (2016), pp. 158 and 178-179.

139 Nowakowski v. Poland, no. 55167/11, ECtHR 24 July 2012, discussed by Jakubowski (2016), p. 176.

140 Syllogos ton Athoinon against the United Kingdom, no. 48259/15, ECtHR 31 May 2016.

141 Ibid.

142 E.g. Art. 18 UDHR; Art. 18 International Covenant on Civil and Political Rights, GA Res. 2200 (XXI) of 16 December 1966, entry into force 23 March 1976 (ICCPR); Art. 9 ECHR.

143 E.g. Art. 8 ECHR.

144 Art. 27 ICCPR: 'In those States in which ethnic, religious or linguistic minorities exist, persons belonging to such minorities shall not be denied the right, in community with the other members of their group, to enjoy their own culture, to profess and practise their own religion, or to use their own language'; Art. 9 ECHR.

145 Which specifically mentions culture, see e.g. Art. 1 ICESCR: 'All peoples have the right of selfdetermination. By virtue of that right they freely determine their political status and freely pursue their economic, social and cultural development'. Emphasis added.
} 
is now Libyan soil. In this ground-breaking (albeit not exemplary) case the Italian Council of State confirmed the view that the return of cultural objects taken during colonial rule is inherent in the right of self-determination of newly independent States. ${ }^{146}$ The right to self-determination, in other words, may include the right to the cultural heritage linked to the territory or peoples of that State.

\subsubsection{Cultural Rights of Indigenous Peoples}

While the right of 'access to culture' in the binding ICESCR may seem vague and unspecified, the 2007 United Nations Declaration on the Rights of Indigenous Peoples (UNDRIP) is clear and specific in its obligations. ${ }^{147}$ The UNDRIP entitles indigenous peoples to rights with regard to their cultural heritage, including their lost cultural property. ${ }^{148}$ In Article 11(2), this is defined as a right of 'redress through effective mechanisms, which may include restitution, developed in conjunction with indigenous peoples, with respect to their cultural, intellectual, religious and spiritual property taken without their free, prior and informed consent or in violation of their laws, traditions and customs'. ${ }^{149}$ Article 12 deals with rights to objects of special importance-providing for a right to 'use and control' where lost ceremonial objects are concerned and a straightforward right to repatriation for objects containing human remains. ${ }^{150}$

Since these provisions are acknowledged as part of the (binding) right of access to culture of Article 15(1)(a) ICESCR insofar as the cultural heritage of indigenous peoples is concerned, this is an important instrument. ${ }^{151}$ That it is more than 'just' a non-binding declaration is also illustrated by the fact that the UNDRIP was adopted after 20 years of negotiations and by now is supported almost universally. ${ }^{152}$ States,

\footnotetext{
146 Consiglio di Stato, 23 June 2008, No. 3154, Associazione nazionale Italia Nostra Onlus c. Ministero per $i$ beni e le attività culturali et al., discussed by Chechi (2008). For a discussion of the importance of the right to self-determination to restitution issues, see Vrdoljak (2006).

147 United Nations Declaration on the Rights of Indigenous Peoples, GA Res. 61/295, UN GAOR, UN Doc. A/RES/61/295 (13 September 2007) (UNDRIP).

148 See also International Labour Organization (ILO) Convention no. 169 Concerning Indigenous and Tribal Peoples in Independent Countries, 27 June 1989, 28 ILM 1382 (1989) (Convention no. 169). It requests States to take special measures to 'safeguard' the cultures of indigenous peoples (Art. 4). The UNDRIP is more specific.

149 UNDRIP, Art. 11(2).

150 UNDRIP, Art. 12(1): 'Indigenous peoples have the right to manifest, practice, develop and teach their spiritual and religious traditions, customs and ceremonies; [...] the right to the use and control of their ceremonial objects; and the right to the repatriation of their human remains. (2) States shall seek to enable the access and/or repatriation of ceremonial objects and human remains in their possession through fair, transparent and effective mechanisms developed in conjunction with indigenous peoples concerned'. 151 According to General Comment No. 21 the right of 'access to culture' includes the rights as listed in the UNDRIP. See also Xanthaki (2018), p. 275. With reference to Res. 5/2012 of the International Law Association, Lenzerini concludes that the right of indigenous peoples to reparation for the wrongs suffered has today crystallized into a principle of customary international law. Lenzerini (2017), p. 336. See also Van Genugten and Lenzerini (2018).

152 It was adopted by a majority of 144 States in favour, 11 abstentions (Azerbaijan, Bangladesh, Bhutan, Burundi, Colombia, Georgia, Kenya, Nigeria, the Russian Federation, Samoa and Ukraine) and four votes against. These objectors all reversed their vote: on 3 April 2009, Australia's government endorsed
} 
in other words, are under the obligation to assist indigenous peoples in providing 'redress through effective mechanisms' and to 'enable the access and/or repatriation of ceremonial objects and human remains in their possession through fair, transparent and effective mechanisms developed in conjunction with indigenous peoples concerned'. ${ }^{153}$

As to the question of what exactly constitutes an indigenous people, the UNDRIP deliberately abstains from a definition to allow for the flexible evolution of the concept. ${ }^{154}$ In general terms the link between people, their land and culture, and selfidentification as a distinct community, are decisive factors. ${ }^{155}$

\subsection{Heritage Title}

Beyond direct applicability in specific cases, the approach followed in UNDRIP highlights three elements that shape the content of heritage title.

\subsubsection{Basis for Entitlement}

First of all, such entitlement is not per se based on the unlawfulness of a loss of ownership in the past, but on the continuing injustice of remaining separated from objects with a specific meaning for people who identify with them.

In many of today's restitution cases, the unlawfulness of the taking at the time is not a given. If a loss occurred during times of historical injustice, such as the Holocaust or colonial rule, often a changing notion of justice and legality is at the core of claims: In some instances the original taking can indeed be classified as unlawful, but in other cases the loss was legal at the time. ${ }^{156}$ In other words, such cases rely on present-day norms that aim to reunite people with cultural objects that have a specific symbolic meaning, and to provide redress for a continuing injustice.

A continuing cultural link and entitlement without regard to the proven unlawfulness of the loss at the time, similarly underlies UNDRIP. In this sense, the notion of 'cultural affiliation' introduced in the American Graves Protection and Repatriation

Footnote 152 (continued)

it; on 19 April 2010, New Zealand's support became official; on 16 December 2010, the United States declared it would 'lend its support', and in 2016, Canada officially adopted the declaration.

153 UNDRIP, Art. 12(2).

154 Following the advice of Special Rapporteur Daes, Commission on Human Rights, Sub-commission on Prevention of Discrimination and Protection of Minorities, 'Discrimination against Indigenous Peoples: Protection of the Heritage of Indigenous People', Final Report (1995), Doc. E/Cn.4.2/1995/26. Also Campfens (2019a), p. 101.

155 See Centre for Minority Rights Development (Kenya) and Minority Rights Group International (on Behalf of Endorois Welfare Council) v. Kenya [2010] Communication No. 276/2003, discussed in Vrdoljak (2016), p. 281.

156 The sale of artefacts by Jewish collectors in the early thirties, before racial laws were enacted by the Nazis, could for example hardly be qualified as unlawful at the time. Still such losses qualify for reparations under the system of the Washington Principles. See e.g. Campfens (2018), p. 325. Likewise, in the 2018 French policy report-The Restitution of African Cultural Heritage. Toward a New Relational Ethics - the term 'restitution' is deliberately used to underline the authors' views on the injustice of colonial acquisition practices, not their unlawfulness. Sarr and Savoy (2018). 
Act is also noteworthy. ${ }^{157}$ It is used to allocate rights to (lost) cultural property of Native Americans of 'ongoing historical, traditional or cultural importance' on the basis of a shared group identity and the (continued) existence of an identifiable group. Likewise, as discussed above (in Sect. 4.1), a continuing cultural link is the rationale for entitlement of States to their lost cultural patrimony. In sum, heritage title depends on a (verifiable) continuing cultural link between people and objects.

\subsubsection{Classification of Objects}

The second element of heritage title is that it enables the classification of objects depending on their social function and identity value for the people involved. UNDRIP differentiates for example between ceremonial objects, objects containing human remains and a general category of cultural objects 'taken without free, prior and informed consent'. Objects that contain human remains or are sacred to a living community, such as the Chinese Buddha statue (Master Zhang Gong) and the Hopi masks (Katsina) in the examples in the introduction, clearly stand out. ${ }^{158}$ Regalia or other objects symbolic to the identity of people are other obvious examples. The way in which objects were lost may enhance that symbolic meaning. For example, this was key in the repatriation of a kris (an Indonesian dagger) that belonged to the 'rebel prince' Diponegoro, who led an uprising against Dutch colonial rule, by the Netherlands, and that of the Witbooi Bible that had once belonged to the Namibian hero Hendrik Witbooi by Germany. ${ }^{159}$ Likewise, also family heirlooms that were lost in the course of racial persecution stand out, as tangible symbols of a (lost) family life. As discussed above (in Sect. 4.1) archaeological objects and elements of a monument form another separate category as these are strongly, and often intrinsically, connected with a territory. ${ }^{160}$

\subsubsection{Rights}

The third element is that the rights involved are defined in terms of access, return or equitable solutions, not in terms of (the restitution of) exclusive ownership rights. Rights, in other words, tailored to the heritage interests involved, and this enables remedies that take account of the interests of other right holders, such as new possessors.

The jurisprudence of the Inter-American Court of Human Rights is noteworthy in this regard, apart from its acknowledgement of pre-existing rights of the indigenous peoples (to their ancestral lands, not cultural objects), in its choice for participatory

\footnotetext{
157 US Native American Graves Protection and Repatriation Act of 16 November 1990 (25 USC paras. 3001-13) (NAGPRA). It recognizes the inalienability of cultural objects with an 'ongoing historical, traditional or cultural importance central to the Native American Group'. See Kuprecht (2012). Obviously, NAGPRA is only binding in the US.

158 A number of soft law instruments underscore this classification. See also Campfens (2019a), para. 2.3.

159 See: https://www.rijksoverheid.nl/actueel/nieuws/2020/03/04/nederland-geeft-dolk-van-javaanseverzetsheld-terug-aan-indonesie) and Neuendorf (2019).

160 E.g. see also the argumentation in the UNSC Resolutions, above nn. 34 and 35.
} 
solutions. In the 2015 Kaliña and Lokono Peoples v. Suriname case the Court held that the right of access can be compatible with the rights of other title holders. ${ }^{161}$

This reflects soft law and (best) practice in the field. The 1998 Washington Principles on Nazi-Confiscated Art, for example, prescribe 'fair and just solutions, depending on the circumstances of the case'. ${ }^{162}$ In a similar spirit, the 2015 Operational Guidelines to the 1970 UNESCO Convention suggest cooperative solutions in the event of competing claims of States 'to realize [...] interests in a compatible way through, inter alia, loans, temporary exchange of objects [...], temporary exhibitions, joint activities of research and restoration'. ${ }^{163}$ Such creative solutions are not uncommon in practice as it is. For example, when France returned looted scriptures to (South) Korea on a renewable long-term loan-to circumvent laws prohibiting French museums to deaccession national patrimony-, it separated ownership rights from rights to access, use and control. ${ }^{164}$ A solution mirrored by the Korean example is the transfer of title of (presumably looted) Nok and Sokoto statuettes by France to Nigeria, whereas they physically remained in France under the terms of a 25-year loan in the Quai Branly Museum. ${ }^{165}$ In the Korean example physical possession, whereas in the Nigerian example rehabilitation and a formal recognition appear to have been key.

The notion of heritage title that thus emerges relies on a (verifiable) continuing cultural link between people and an object. Dependant on the type of object and the values it represents, it entitles people to an equitable solution. The specific circumstances and interests involved, including the interests of other right holders, should determine what is 'equitable'.

\subsection{Operationalisation of Heritage Title}

The last question that needs to be addressed is how to make heritage title operational. Alternative dispute resolution and cultural diplomacy on the interstate level

\footnotetext{
161 The Court ruled with respect to ancestral land that was now owned by third parties that 'the State must establish, by mutual agreement with the Kaliña and Lokono peoples and the third parties, rules for peaceful and harmonious coexistence in the lands in questions, which respect the uses and customs of these peoples and ensure their access to the Marowijne River'. Kaliña and Lokono Peoples v. Suriname, Merits, Reparations and Costs, Inter-Am. Ct HR, Series C, No. 309, 25 November 2015, para. 159.

162 These solutions often involve a financial settlement, but recognition by addressing the ownership history (e.g. in a plaque in a museum) also features as a 'fair solution'. In the words of a claimant at the Dutch Restitutions Committee: 'Our objective is not to recover every stolen work of art. For us it's about recognition. The most important issue for us is that the name of our great-grandfather is restored into the work's provenance', in Marck and Schoonderwoerd (2015), pp. 147-148.

163 Operational Guidelines for the Implementation of the Convention on the Means of Prohibiting and Preventing the Illicit Import, Export and Transfer of Ownership of Cultural Property, adopted at the UNESCO Meeting of States Parties, 18-20 May 2015 (C70/15/3.MSP/11), para. 19.

164 Décret No. 2011-527 Portant Publication de l'Accord entre le Gouvernement de la République Française et le Gouvernement de la République de Corée Relatif aux Manuscrits Royaux de la Dynastie Joseon (Ensemble une Annexe) (7 February 2011), https://www.legifrance.gouv.fr/eli/decret/2011/5/16/ MAEJ1111118D/jo.

165 Cornu and Renold (2010), pp. 20-21.
} 
are often promoted as being best equipped to solve disputes in this field. ${ }^{166}$ However valid this may be in specific cases, access to justice is eventually key, not only in the recognition of unequal power relations, but also for the development of standards in a field that is hindered by legal insecurity. ${ }^{167}$

The question if norms can be made operational obviously depends on the binding force of norms that a party invokes for its heritage title. Here, hurdles exist as the law is evolving. Nevertheless, even if the mentioned norms would not be directly applicable in a court of law, heritage title may operate as a 'narrative norm'. ${ }^{168} \mathrm{Her}-$ itage title should thus instruct judges on the interpretation of open norms that exist in all jurisdictions, for example through the application of concepts such as '(international) public policy', 'morality', 'general principles of (international) law' or 'reasonableness and fairness'. In fact, courts in various countries have already prevented unjust outcomes to cultural property disputes in a strict private law approach in that way. ${ }^{169}$ In that setting of dispute resolution before national courts, the notion that the private sector should adhere to human rights standards, as advocated by the UN, may be relevant in cases where auction houses, art dealers or private museums are involved. ${ }^{170}$

In terms of a straightforward human rights claim, the question is whether a forum could evaluate a claim based on the argument that the continued deprivation of a specific cultural object is an infringement of the right to 'access to culture'. In this respect, the Optional Protocol to the ICESCR offers a complaints procedure. This procedure, however, appears limited to nationals or groups in the State responsible for the alleged violation, whereas claimants are not usually nationals of a holding

\footnotetext{
166 E.g. the International Law Association's Principles for Co-operation in the Mutual Protection and Transfer of Cultural Material: 'If the [... parties, EC] are unable to reach a mutually satisfactory settlement [...] both parties shall submit the dispute to good offices, consultation, mediation, conciliation, ad hoc arbitration or institutional arbitration'. International Law Association, Report of the Seventy-second Conference (2006), Principle 9. Annex to Nafziger (2007), p. 159; cf. Frigo (2017), pp. 569-598.

167 Campfens (2019b). See also Shyllon (2017).

168 Jayme (2015), p. 41: 'These norms speak, but they are flexible and not very precise. They describe certain policies without giving answers in a single case'. As an example, he refers to the 1998 Washington Principles that judges should take into account.

169 Above n. 64, examples from Switzerland (relying on 'international public policy') and Germany (relying on 'the morality of the international trade'). Two UK examples, relying on 'public policy' and 'public order': (1) City of Gotha and Federal Republic of Germany v. Sotheby's and Cobert Finance SA (1998, 1993 C 3428 (QB)), where Judge Moses observed that he would have invoked the public order exception if the application of foreign (German) law had necessitated a ruling in favour of a new possessor who was aware of the painting's tainted provenance (it was stolen in the aftermath of WWII); and (2) Government of the Islamic Republic of Iran v. The Barakat Galleries Ltd.[2007] EWCA Civ. 1374: '[I]n our judgment it is certainly contrary to public policy for such claims [by a State to recover antiquities which form part of its national heritage] to be shut out [...]. There is international recognition that States should assist one another to prevent the unlawful removal of cultural objects including antiquities'. 170 See the UN Guiding Principles on Business and Human Rights: Implementing the United Nations 'Protect, Respect and Remedy' Framework. Report of the Special Representative of the Secretary-General on the issue of human rights and transnational corporations and other business enterprises, John Ruggie, presented to the seventeenth session of the Human Rights Council of the United Nations, A/ HRC/17/31 (21 March 2011).
} 
State, and is subject to ratification of the Protocol by that State. ${ }^{171}$ Within the European human rights system, while a stumbling block is that the European Convention on Human Rights does not include a right to culture, claims may be addressed through the right to property of the First Protocol, or other rights, as mentioned above. $^{172}$

Lastly, an interesting roadmap on how to proceed is given by the Colombian Constitutional Court in a 2017 case concerning the 'Quimbaya Treasure'. ${ }^{173}$ In its ruling, the Court ordered the Colombian government to pursue-on behalf of the indigenous Quimbaya people - the return from Spain of a treasure of 122 golden objects lost at the close of the nineteenth century. The Court argued that under today's standards of international law, referring to human rights law and UNDRIPbut interestingly also to the 1970 UNESCO Convention-, indigenous peoples are entitled to their lost cultural objects. How such a claim is pursued is left to the discretion of the government, but according to the Court the fact that governments should work towards this goal is clear. ${ }^{174}$ In a first reaction to the subsequent request by the Colombian authorities for the return of the Quimbaya Treasure, the Spanish authorities, however, declined on the grounds that today the Quimbaya Treasure has become Spanish patrimony and is inalienable.

As discussed earlier in this article, that has long been a common European reaction to restitution requests by former colonized people. ${ }^{175}$ It is also reminiscent of the (initial) position that the Austrian government took in the Altmann case: due to national administrative law (patrimony laws) the Klimt paintings that were lost during the Nazi era were inalienable. In that case, however, after US Supreme Court established a violation of international human rights law, the Austrian government accepted to abide by an arbitral award that the rights of Altmann should prevail. ${ }^{176}$

It illustrates the difficulties in this field and the clash of laws on various levels, but also highlights the potential of the human rights framework as a universal language to further develop this field.

\section{Conclusion}

'Hard cases make bad law', so the maxim goes. A question at the conclusion of this article is whether cases such as those mentioned in the introduction are indeed hard and exceptional-which no law can address-or whether the law is in need of change. The analysis in this article illustrates that title disputes about contested

\footnotetext{
171 Optional Protocol to the International Covenant on Economic, Social and Cultural Rights (adopted 10 December 2008), UN Doc. A/RES/63/117 (5 March 2009), Art. 2: 'Communications may be submitted by or on behalf of individuals or groups of individuals, under the jurisdiction of a State Party, claiming to be victims of a violation of any of the economic, social and cultural rights set forth in the Covenant by that State Party'. Emphasis added.

172 Above n. 22.

173 Judgment SU-649/17 (2017) (Republic of Colombia, Constitutional Court).

174 For a critical discussion, see Mejia-Lemos (2019).

175 See above Sect. 4.2 for a similar argumentation.

176 Above n. 97.
} 
cultural objects are indeed complex: international and domestic, public and private laws of different places and times, as well as soft law, meet and not seldom clash. On the other hand, if claims to cultural heritage cannot be addressed on their merits in our courts of law due to the inflexibility of private law, the law is up for a change.

Given the rhetoric on the importance of heritage protection for humanity at large, not only on account of the intrinsic value of cultural objects but because destruction and looting are detrimental to the sustainable development of societies and the realization of human rights, one would expect that the trade and possession of looted cultural objects would be more difficult than it is today. The illegality of the act of looting simply does not 'stick' to the objects. This, in spite of the introduction fifty years ago of the 1970 UNESCO Convention to curb the one-way traffic of cultural objects from culturally rich source countries to Western market countries. Through trade and acquisition ownership title is passed on, or 'laundered' in civil law countries. Often, the provenance of a specific object (its ownership history) is omitted or unknown by new possessors along the line. A first step to counter the illicit trade is therefore to oblige actors in the art world to abide by clear due diligent standards: to only trade, buy and possess objects that have a documented lawful provenance. The need for measures in that regard resonates even in the UN Security Council. ${ }^{177} \mathrm{Nev}-$ ertheless, this will still not solve title issues in a private law setting for objects that already circulate: who should be seen as legitimate 'title holders' when ownership laws differ per jurisdiction?

As demonstrated in this article, neither traditional ownership concepts nor the conventional regime for the art trade are particularly suited to solve title issues with regard to contested cultural objects. The 1970 UNESCO Convention operates on the interstate level and was primarily set up as a means to control the movement of cultural objects, not to provide answers for competing claims. Moreover, the 1995 UNIDROIT Convention, meant to harmonize private law, has not been ratified by market States, and none of the conventions cover earlier losses. This adds up to a highly fragmented framework where States implement standards in different ways, not seldom primarily to protect their own heritage. That is not surprising, given that the 1970 UNESCO Convention appoints States as exclusive right holders ('owners') of their national cultural heritage. Nationality alone, however, is insufficient to decide the matter of title, as it fails to acknowledge that the value of cultural objects may change in time and place. Such blind spots surface in dispute resolution over artefacts that left their original setting, where parties claiming 'their' heritage may be States, but also communities or private individuals. Mostly if communities or individuals do not (or no longer) feel represented by a State, nationality proves insufficient.

To entangle the matter of title, the notion of heritage title was introduced. It is based on a (verifiable) continuing cultural link that entitles people with rights defined in terms of access and control, not in terms of absolute and exclusive ownership. Although we are used to define relations between objects and people by way of exclusive ownership rights, this exclusivity does not fit cultural property. Owners of certain 'outstanding' artefacts are not free to destroy, or alienate such objects,

177 UNSC Res. S/RES/2347 (2017). 
as this could be contrary to the (heritage) interests of the wider public: preservation and accessibility are well accepted public interests that limit private ownership. Similarly, and more directly, the interests of specifically interested people beyond the wider public, such as former owners or creators who are tied to the objects on the basis of a continuing cultural link, limit the rights of (new) owners.

International human rights law is particularly suited to further develop this field: it addresses identity values, is of a universal nature and may penetrate and shape private law. As such, it can act as a bridge for internationally acknowledged heritage interests onto national private law settings. Various human rights may inform heritage title, depending on the facts of a case. The right of access to culture, as developed in the realm of the right to culture in Article 15(1) ICESCR, is of key importance. Furthermore, the rights provided in UNDRIP are relevant for indigenous peoples' lost cultural objects, whereas the human right to property is the logical basis to further develop heritage title of dispossessed private former owners (e.g. the field of Nazi-looted art).

Heritage title that thus surfaces is based on a continuing cultural link and three elements shape its content. In the first place, not to be able to have access to or control over objects over which one has heritage title-after removal without free consent - implicates a continuing injustice of remaining separated from those objects. Such an outlook brings with it a shift in focus from past events- the unlawfulness of the loss that is decisive in an ownership approach-to present-day interests. In the second place, the rights involved are defined in terms of access, control, return or 'equitable solutions', as opposed to the restitution of full ownership rights. This enables the weighing, and ideally conciliation, of competing interests that parties may have in the same object by aiming at creative and participatory solutions. A third element is the classification of cultural objects depending on their specific social function and heritage value. In that sense, for example, sacred or other highly symbolic objects stand out on account of their identity value for the people involved, whereas an artefact produced for the market will not easily pass the test for heritage title unless such artefact turned into a tangible symbol for a (lost) family or community life.

Obviously, heritage title may coincide with ownership title and, where this is the case, there is no need to rely on heritage title in dispute resolution. Furthermore, where no heritage title in terms of a continuing cultural link can be proven, cases fall under regular ownership laws. However, in all those cases in the 'grey' categories of lawfully possessed but unlawfully taken artefacts, heritage title could be invoked. In the case concerning 'Master Zhang Gong', introduced at the start of this article, the Chinese communities could rely on a strong heritage title with regard to their lost sacred statue irrespective of the ownership situation in a specific jurisdiction. This implicates a right of access and control that, given the religious function for the local community, would mean a return in its original setting. And what about the owner of an object that, on closer examination, is encumbered with heritage title? According to rules already operative in the art world, that owner's position should depend on its due diligence on acquisition, most notably the provenance research performed. 
Acknowledgements I am indebted to the reviewers of the NILR, in particular Nico Schrijver, and to Lucas Lixinsky, Sophie Starrenburg and Wouter Veraart, for their valuable comments on an earlier version.

Open Access This article is licensed under a Creative Commons Attribution 4.0 International License, which permits use, sharing, adaptation, distribution and reproduction in any medium or format, as long as you give appropriate credit to the original author(s) and the source, provide a link to the Creative Commons licence, and indicate if changes were made. The images or other third party material in this article are included in the article's Creative Commons licence, unless indicated otherwise in a credit line to the material. If material is not included in the article's Creative Commons licence and your intended use is not permitted by statutory regulation or exceeds the permitted use, you will need to obtain permission directly from the copyright holder. To view a copy of this licence, visit http://creativecommons.org/licen ses/by/4.0/.

\section{References}

Abungu G (2009) The Declaration: a contested issue. In: Prott LV (ed) Witnesses to history: a compendium of documents and writings on the return of cultural objects. UNESCO, Paris, pp 121-122

Bauer AA (2007) New ways of thinking about cultural property: a critical appraisal of the antiquities trade debates. Fordham Int Law J 31:690-724

Bindenagel JD (1999) Washington Conference on Holocaust-Era Assets. US Government Printing Office, Washington DC

Blake J (2015) International cultural heritage law. Oxford University Press, Oxford

Brodie N (2017) Protection not preventing: the failure of public policy to prevent the looting and illegal trade of cultural property from the MENA Region (1990-2015). In: Anderson J, Geismar H (eds) The Routledge companion to cultural property. Routledge, New York, pp 89-108

Brown K (2020) Sotheby's just lost its lawsuit against Greece over an 8th-century BC horse statue-and the decision may have lasting implications for the trade. 10 June 2020. https://news.artnet.com/artworld/barnet-case-sothebys-1883349. Accessed 27 July 2020

Campbell PB (2013) The illicit antiquities trade as a transnational criminal network: characterizing and anticipating trafficking of cultural heritage. Int J Cult Prop 20:113-153

Campfens E (2017) Whose cultural heritage? Crimean treasures at the crossroads of politics, law and ethics. Art Antiq Law 22:193-213

Campfens E (2018) Nazi-looted art: a note in favour of clear standards and neutral procedures. Art Antiq Law 22:315-347

Campfens E (2019a) The Bangwa queen: artifact or heritage? Int J Cult Prop 26:75-110

Campfens E (2019b) Restitution of looted art: what about access to justice? Santander Art Cult Law Rev 2/2018 4:185-220

Campfens E (2020) Bridging the gap between ethics and law: the Dutch framework for Nazi looted art. Art Antiq Law 25:1-25

Chechi A (2008) The return of cultural objects removed in times of colonial domination and international law: the case of the Venus of Cyrene. Ital Yearb Int Law 18:159-181

Chechi A (2014) The settlement of international cultural heritage disputes. Oxford University Press, New York

Chrysopoulos P (2019) Greek ministry of culture in legal dispute over return of 8th century BC antiquity. Greek Reporter, 25 September 2019. https://greece.greekreporter.com/2019/09/25/greek-ministryof-culture-in-legal-dispute-over-return-of-8th-century-bc-antiquity/. Accessed 20 Apr 2020

Cornu M, Renold MA (2010) New developments in the restitution of cultural property: alternative means of dispute resolution. Int J Cult Prop 17:1-31

Council of Europe, Research Division (2011) Cultural rights in the case-law of the European Court of Human Rights. Council of Europe/European Court of Human Rights, January 2011

De Gaetano N (2019) On the right of the government of Malta to restrict the movement of cultural objects situated in Malta. Art Antiq Law 24:79-86 
Dromgoole S (2013) Underwater cultural heritage and international law. Cambridge University Press, Cambridge

Fiorentini F, Hausler K, Jagielska-Burduk A, Jakubowski A (2016) Editorial. Santander Art. Law Rev 2:9-21

Francioni F (2011) The human dimension of international cultural heritage law: an introduction. Eur J Int Law 22:9-16

Francioni F (2019) General principles applicable to international cultural heritage law. In: Andenas M, Fitzmaurice M, Tanzi A, Wouters J (eds) General principles and the coherence of international law. Queen Mary Studies in International Law. Brill, Leiden, pp 389-407

Frigo M (2017) Methods and techniques of dispute settlement in the international practice of the restitution and return of cultural property. Rivista di Diritto Internazionale Privato e Processuale 53:569-598

Gerstenblith P (2013) Enforcement by domestic courts, criminal law and forfeiture in the recovery of cultural objects. In: Francioni F, Gordley J (eds) Enforcing international cultural heritage law. Oxford University Press, Oxford, pp 150-167

Gerstenblith P (2020) The disposition of movable cultural heritage. In: Carstens A-M, Varner E (eds) Intersections in international cultural heritage law. Oxford University Press, Oxford, pp 17-56

Global Times (2018) Looted 3,000-year-old 'Tiger Ying' bronze vessel donated by mysterious buyer returns to China. Global Times, 11 December 2018. https://www.globaltimes.cn/content/11313 43.shtml. Accessed 23 July 2020

Gordley J (2013) The enforcement of foreign law: reclaiming one's nation's cultural heritage in another nation's courts. In: Francioni F, Gordley J (eds) Enforcing international cultural heritage law. Oxford University Press, New York, pp 110-124

Hafstein TV, Skrydstrup M (2017) Heritage vs. property, contrasting regimes and rationalities in the patrimonial field. In: Anderson J, Geismar H (eds) The Routledge companion to cultural property. Routledge, New York, pp 38-54

Hausler K (2020) The UN Security Council, the Human Rights Council, and the protection of cultural heritage: a matter of peace and security, human rights, or both? In: Carstens A-M, Varner E (eds) Intersections in international cultural heritage law. Oxford University Press, Oxford, pp 202-220

Hooper J, Plafker T (2017) The body in the Buddha. The Economist, 4 May 2017. www.1843magazi ne.com/features/the-body-in-the-buddha. Accessed 29 Apr 2020

Jakubowski A (2016) Cultural heritage and the collective dimension of cultural rights in the jurisprudence of the European Court of Human Rights. In: Jakubowski A (ed) Cultural rights as collective rights, an international law perspective. Brill, The Hague, pp 155-179

Jayme E (2015) Narrative norms in private international law, the example of art law. The Hague Academy of International Law, Recueil des cours, Collected Courses, vol 375. Brill-Nijhoff, Leiden, pp 9-52

Kuprecht K (2012) The concept of 'cultural affiliation' in NAGPRA: its potential and limits in the global protection of indigenous cultural property rights. Int J Cult Prop 19:33-63

Kuprecht K (2014) Indigenous peoples' cultural property claims. Springer International Publishing, Cham

Lenzerini F (2017) Reparations for wrongs against indigenous people's cultural heritage. In: Xanthaki A, Valkonen S (eds) Indigenous peoples' cultural heritage: rights, debates, challenges. Brill, The Hague, pp 327-346

Liu Z (2017) Will the god win? the case of the Buddhist mummy. Int J Cult Prop 24:221-238

Lixinski L (2019) International heritage law for communities, exclusion and re-imagination. Oxford University Press, New York

Marck A, Schoonderwoerd M (2015) 'We want to honour the memory of our great-grandparents'and interview with Ella Andriesse and Robert Sturm. In: Campfens E (ed) Fair and just solutions, alternatives to litigation in Nazi-looted art disputes: status quo and new developments. Boom, The Hague, pp 141-153

Mejia-Lemos D (2019) The 'Quimbaya treasure' judgment SU-649/17. Am J Int Law 113:122-130

Merryman JH (1986) Two ways of thinking about cultural property. Am J Int Law 80:831-853

Merryman JH (1996) Note on the Marquis de Somerueles. Int J Cult Prop 5:321-329

Merryman JH (2005) Cultural property internationalism. Int J Cult Prop 12:11-39

Nafziger JAR (2007) The principles for cooperation in the mutual protection and transfer of cultural material. Chic J Int Law 8:147-167 
Nafziger JAR (2008) Cultural heritage law: the international regime. Centre for studies and research in international law and international relations. The cultural heritage of mankind. Académie de droit international de La Haye. Brill/Nijhoff, Leiden/Boston, pp 145-274

Nafziger JAR, Paterson RK (2014) International trade in cultural material. In: Nafziger JAR, Paterson RK (eds) Handbook on the law of cultural heritage and international trade. Edward Elgar, Cheltenham, pp 19-44

Négri V (2015) Legal study on the protection of cultural heritage through the resolutions of the Security Council of the United Nations. UNESCO Unite4Heritage. https://www.unesco.org/new/fileadmin/ MULTIMEDIA/HQ/CLT/pdf/Study_Negri_RES2199_01.pdf. Accessed 31 July 2020

Neuendorf H (2019) Germany is returning artifacts stolen from a Namibian freedom fighter during its colonial rule. Artnet News. https://news.artnet.com/art-world/germany-namibia-restitution-14671 45. Accessed 23 July 2020

Nicolazzi L, Chechi A, Renold MA (2015) Case Hopi masks-Hopi tribe v. Néret-Minet and estimations \& ventes aux enchères. Platform ArThémis, Art-Law Centre, University of Geneva. https://plone .unige.ch/art-adr/cases-affaires/hopi-masks-2013-hopi-tribe-v-neret-minet-and-estimations-vente S-aux-encheres. Accessed 23 July 2020

Peters R (2016) The protection of cultural property: recent developments in Germany in the context of new EU law and the 1970 UNESCO Convention. Santander Art Cult Law Rev 2:85-102

Peters R (2020) Nationalism versus internationalism. New perspectives beyond state sovereignty and territoriality in the protection of cultural heritage. In: Carstens A-M, Varner E (eds) Intersections in international cultural heritage law. Oxford University Press, Oxford, pp 364-388

Ploeger HD, Stolker CJJM (2000) In search of the importance of Article 1 Protocol no. 1 ECHR to private law. In: Loof JP, Ploeger HD, Van der Steur A (eds) The right to property: the influence of Article 1 Protocol no. 1 ECHR on several fields of domestic law. Shaker, Maastricht, pp 69-89

Prott LV (2009) Witnesses to history, a compendium of documents and writings on the return of cultural objects. UNESCO, Paris

Prott LV, O'Keefe PV (1992) Cultural heritage or cultural property? Int J Cult Prop 1:307-320

Renold C, Chechi A, Bandle AL, Renold MA (2012) Case six Klimt paintings-Maria Altmann and Austria. Platform ArThemis, Art-Law Centre, University of Geneva. https://plone.unige.ch/art-adr/cases -affaires/6-klimt-paintings-2013-maria-altmann-and-austria. Accessed 23 July 2020

Robertson G (2019) Who owns history? Elgin's loot and the case for returning plundered treasure. Knopf, Melbourne

Sarr F, Savoy B (2018) The restitution of African cultural heritage: toward a new relational ethics. https:// restitutionreport2018.com/sarr_savoy_en.pdf. Accessed 23 July 2020

Schrijver NJ (2016) Managing the global commons: common good or common sink? Third World Q 37(7):1252-1267

Shyllon F (2017) The rise of negotiation (ADR) in restitution, return and repatriation of cultural property: moral pressure and power pressure. Art Antiq Law 22:130-142

Siehr K (1993) International art trade and the law. In: The Hague Academy of International Law (ed) Collected courses of the Hague academy of international law 243:9-292

Siehr K (2015) Private law and the difficult problem to return illegally exported cultural property. Unif Law Rev 20:503-515

Sprankling JG (2014) The international law of property. Oxford University Press, New York

Stamatoudi IA (2011) Cultural property law and restitution: a commentary to international conventions and European Union law. Edward Elgar, Massachusetts

Tao D (2009) Issue on conflict law in overseas litigation for the recovery of lost cultural relics-Iranian government v. Barakat Art Museum and its enlightenment. Comparative Law Study 2 (in Chinese)

UNESCO Secretariat (1970) Working paper. In: Cultural rights as human rights. UNESCO Studies and documents on cultural policies No 3. SHC.68/XIX.3/A, pp 9-14. https://unesdoc.unesco.org/ ark:/48223/pf0000001194?posInSet=1\&queryId=a4ebebf6-bc78-4ca2-8005-d9f3a5a8e266. Accessed 4 Aug 2020

Van Genugten W, Lenzerini F (2018) Legal implementation and international cooperation and assistance: articles 37-42. In: Hohmann J, Weller M (eds) The UN declaration on the rights of indigenous peoples: a commentary. Oxford University Press, Oxford, pp 539-572

Vrdoljak AF (2006) International law, museums and the return of cultural objects. Cambridge University Press, Cambridge 
Vrdoljak AF (2014) Human rights and cultural heritage in international law. In: Lenzerini F, Vrdoljak AF (eds) International law for common goods: normative perspectives on human rights, 1st edn. Hart Publishing, Oxford, pp 139-174

Vrdoljak AF (2016) Standing and collective cultural rights. In: Jakubowski A (ed) Cultural rights as collective rights, an international law perspective. Brill, Leiden, pp 272-287

Wong E (2016) Ai Weiwei's animal heads offer critique of Chinese nationalism. The New York Times, 10 August 2016. https://www.nytimes.com/2016/08/11/world/asia/china-ai-weiwei-zodiac.html. Accessed 24 Apr 2020

Xanthaki A (2018) Culture: Articles 11(1), 12, 13(1), 15, and 34. In: Hohmann J, Weller M (eds) The UN Declaration on the Rights of Indigenous Peoples: a commentary. Oxford University Press, Oxford, pp 273-298

Zhang Y (2018) Customary international law and the rule against taking cultural property as spoils of war. Chin J Int Law 17:943-989

Zhen L (2009) Examining the recovery of Yuanmingyuan cultural property from the perspective of international law. Legal System and Society 4 (in Chinese)

Publisher's Note Springer Nature remains neutral with regard to jurisdictional claims in published maps and institutional affiliations. 